\title{
Cultura Cultura
}

\section{Um sonho cor-de-rosa}

Propaganda, ideologia e (não-)imagens do matrimónio nos filmes de 'comédia à portuguesa'

\section{Bruno Marques}

\section{(2) OpenEdition}

1 Journals

\section{Edição electrónica}

URL: http://journals.openedition.org/cultura/2626

DOI: $10.4000 /$ cultura.2626

ISSN: 2183-2021

\section{Editora}

Centro de História da Cultura

\section{Edição impressa}

Data de publição: 1 Dezembro 2016

Paginação: 289-333

ISSN: 0870-4546

\section{Refêrencia eletrónica}

Bruno Marques, « Um sonho cor-de-rosa », Cultura [Online], vol. 35 | 2016, posto online no dia 20

fevereiro 2018, consultado a 23 abril 2019. URL : http://journals.openedition.org/cultura/2626 ; DOI : $10.4000 /$ cultura.2626

Este documento foi criado de forma automática no dia 23 Abril 2019.

(c) $\mathrm{CHAM}$ - Centro de Humanidades / Centre for the Humanities 


\section{Um sonho cor-de-rosa}

Propaganda, ideologia e (não-)imagens do matrimónio nos filmes de 'comédia à portuguesa'

\section{Bruno Marques}

\section{NOTA DO AUTOR}

Investigação financiada pela FCT (bolsa de pós-doutoramento [RH/BPD/93234/2013]) e desenvolvida no âmbito do Projecto FCT "Fotografia Impressa. Imagem e Propaganda em Portugal (1934-1974)" [PTDC/CPC-HAT/4533/2014].

[...] a ideologia foi tanto mais eficaz quanto menos política pareceu.

LUÍS TRINDADE, O Estranho Caso do Nacionalismo Português. 0 Salazarismo entre a literatura e a política. Imprensa de Ciências Sociais, 2008, p. 321.

\section{Introdução}

1 A relação entre propaganda e vida privada como campo de investigação e de estudo no Estado Novo português é relativamente recente e ainda se encontra num estado algo seminal, representando um importante contributo para a discussão do modo como o regime se legitimou. É neste sentido que o presente texto aborda a ideia de propaganda indirecta no cinema enquanto dispositivo ideológico de controlo dos costumes, particularmente no que toca às esferas privada, familiar e passional.

2 Com base em sete comédias marcantes do chamado 'período de ouro' do cinema português - A Canção de Lisboa (1933), o Pai Tirano (1941), o Pátio das Cantigas (1942), o Costa do Castelo (1943), A Menina da Rádio (1944), A Vizinha do Lado (1945) e O Leão da Estrela (1947) -, habitualmente considerado como o género mais representativo do período inicial do Estado Novo, o presente ensaio aborda de modo exploratório a forma como foram tratados os papéis do feminino e do masculino no que à intriga amorosa conducente ao 
casamento diz respeito, sob um particular regime ditatorial. Para tal, alguns tópicos correlacionados são trazidos à colação. Por exemplo, como eram dramatizados no grande ecrã os rituais ligados à manifestação dos afectos, as estratégias de "sedução", os protocolos que regulamentavam os namoros, o papel dos "pudores" e da vigilância familiar; como o casamento era idealizado e qual o seu estatuto enquanto projecto de vida; como eram vividos os dilemas passionais, os amores proibidos, as relações extraconjugais e os triângulos amorosos.

Neste âmbito, dois objectivos centrais correlacionados motivaram a nossa investigação: o primeiro, compreender porque foram os filmes de 'comédia à portuguesa' mais eficientes do que os de propaganda directa na promoção da ideologia do Estado Novo, especialmente no que ao casamento diz respeito. $O$ segundo, saber por que razão a representação da "vida em comum" a dois é, nestes filmes, claramente evitada na sua dimensão privada e quotidiana.

4 Para além das análises que, sublinhando a sobredeterminação da cultura pela política, apostam numa causalidade quase transparente e absoluta entre os filmes, os discursos políticos e a ideologia do Estado $\mathrm{Novo}^{1}$ - regime marcadamente conservador e convergente com a visão da Igreja Católica na aprovação de valores como a heterossexualidade, a monogamia, o casamento e a procriação ${ }^{2}$-, pretendemos explorar igualmente a possibilidade de serem feitas leituras contra-hegemónicas, não deixando (de acordo com a proposta afiançada por Marc Ferro de uma "contra-análise da sociedade") ${ }^{3}$ de assinalar "temas latentes" e ocultações, contradições e lacunas e nunca ignorando assim factores de tensão e de perturbação que também encontramos nestes filmes no que concerne à moral e aos bons costumes.

5 No cruzamento de projectos estéticos e políticos nem sempre coincidentes, nem tudo deve ser visto e lido à luz de uma retórica coerente e auto-explicativa do Estado Novo. E a fim de nos afastarmos da visão monolítica e personalizada do regime que os estudos mais recentes sobre o Estado Novo têm vindo a desconstruir, devemos procurar perspectivas alternativas ao pressuposto declarado de que "existe uma confluência entre a imagem do país representada nestas obras e o retrato do governo de Salazar elaborado pelos ideólogos do regime". ${ }^{4}$

Embora história e cinema não se identifiquem em absoluto, mesmo que sejam narrativas que se tocam ao ponto de podermos ser tentados por vezes a deixar que se confundam, o cinema de ficção traduz o imaginário e a capacidade criativa do autor a partir de um dado contexto social e cultural. Cabe-nos assim ler criticamente estas obras de produção cinematográfica como um registo ficcionado de aproximação ao conhecimento da realidade histórica e sociológica sobre as dinâmicas das intrigas passionais e a centralidade da ideia de casamento. Mas antes importa esclarecer primeiro alguns conceitos e contextos que a este tema estão directamente associados.

\section{Vida privada, género e desigualdade/divisão do trabalho}

7 É no decorrer do século XIX que a divisão do trabalho com base no sexo se afirma como elemento constitutivo da ideologia da emergente sociedade burguesa. Nesse sentido, a progressiva especialização da actividade económica irá restringir-se à alçada masculina, reservando-se à mulher a esfera doméstica e privada. Ao mesmo tempo a família 
consolida-se como unidade de reprodução e de consumo e as identidades de género são, desse modo, fortemente vincadas e separadas, circunscrevendo papéis, aspirações e desígnios distintos. 0 desenvolvimento económico e a política liberal contribuíram para o processo de consolidação do padrão masculino do chefe de família e provedor da economia familiar. Com efeito, o Estado Novo vai reabilitar a ideia da diferença de género, mais propriamente, com a Constituição de 1933, que enuncia a igualdade dos cidadãos perante a lei e a "negação de qualquer privilégio de nascimento, nobreza, título nobiliárquico, sexo ou condição social". Porém, logo a seguir uma pequena cláusula: "salvo, quanto às mulheres, as diferenças da sua natureza e do bem da família". ${ }^{5}$ Do ponto de vista discriminatório, Irene Pimentel dá conta deste 'pormenor' nevrálgico:

[...] a apregoada «superioridade» feminina era derivada da sua função «natural»portanto biológica. Como a ideologia salazarista não se pautou pelos conceitos de «cidadania», de «igualdade» e de «liberdade», só aceitou o princípio da «diferença sem a igualdade» em vez «da igualdade na diferença», reservou às mulheres uma esfera própria de actuação - privada e pública - mas não atribuiu ao espaço feminino um valor igual ao do masculino porque o subalternizou hierarquicamente em função do sexo. ${ }^{6}$

O Estado Novo segue, assim, o pensamento oitocentista, segundo o qual os homens estão do lado da cultura e as mulheres do da "natureza". Mas o salazarismo acrescenta que esta ainda deve ser uma mãe devota à pátria, ocupando-se do "governo doméstico". ${ }^{7}$ Assim o atestam as próprias palavras do Presidente do Conselho numa conferência realizada em 1933 na Associação Comercial do Porto: "O trabalho da mulher fora do lar desagrega este, separa os membros da família, torna-os um pouco estranhos uns aos outros. Desaparece a vida em comum, sofre a obra educativa das crianças, diminui o número destas". ${ }^{8}$

\section{A Família como fundamento da ordem: um casamento para toda a vida}

Em matéria de casamento, devemos atender, tal como vimos, que o Estado Novo preconiza a ideologia consolidada da "diferença natural dos sexos" assente no princípio da dissemelhança e da complementaridade dos papéis atribuídos à mulher e ao homem. $\mathrm{Na}$ linha deste pensamento, o salazarismo promove a complementaridade dos cônjuges como forma de garantir a estabilidade da família, evidenciada nos direitos individuais. Enquanto "fonte da conservação e do desenvolvimento da raça" e "fundamento de toda a ordem política", a Família, como instituição, constituiu, assim, o elemento que assegura o bom funcionamento da sociedade e sua "regeneração". 9

Por isso se compreende que

Do ponto de vista moral, a união conjugal também era para toda a vida, mesmo que fenecesse o amor entre os esposos. Como Anália Torres (1987) sublinha, só a partir dos anos 1960 é que os casais portugueses se começam a mentalizar que o amor deve manter-se ao longo da vida em comum. Na década anterior, a perda do afeto não justificava a separação. Com amor ou sem ele, marido e mulher estavam destinados a honrar o compromisso. Os divorciados eram vistos com desconfiança, reprovação e frequentemente proibidos de certos convívios sociais. ${ }^{10}$

11 Só após a queda do regime é que o enquadramento legal que regula o matrimónio e a família se altera.

A lei que consagra a dissolução do casamento católico, em 1975, bem como um conjunto de leis que consagram a igualdade de direitos entre homens e mulheres, a 
expansão da utilização de contraceptivos, como regulador da natalidade, e a responsabilização de homens e mulheres pela educação dos filhos são responsáveis, entre outros factores por uma tendencial democratização das relações conjugais, hoje mais facilmente identificáveis. ${ }^{11}$

\section{Propaganda e cinema}

12 A propaganda, como conceito, ${ }^{12}$ é definida por Richard Alan Nelson enquanto "forma propositada e sistemática de persuasão que visa influenciar com fins ideológicos, políticos ou comerciais, as emoções, atitudes, opiniões e acções de públicos-alvo através da transmissão controlada de informação parcial (que pode ou não ser factual) através de canais directos e de média" (Nelson, 1996). Derivado da Congregatio de Propaganda Fide (Congregação para a Propagação da Fé) - organização de cardeais católicos romanos estabelecida em 1622 pelo Papa Gregório XV para supervisionar a propagação da fé cristã nas missões estrangeiras ${ }^{13}$-, originalmente o termo não implicava uma conotação pejorativa, sendo que o seu sentido político actual remonta à Primeira Grande Guerra. Com efeito, a propaganda adquire particular relevo no século XX justamente, por tirar partido das grandes evoluções tecnológicas. O consumo massificado de informação levou à difusão da imprensa escrita e radiofónica, assim como à disseminação em larga escala da imagem e da fotografia, em particular através do cinema e da televisão, criando um novo campo a explorar que podemos designar de mass media. Através deste padrão de consumo, promovido com o advento do capitalismo, a mensagem a difundir pode agora ser transmitida a um espectro muito mais vasto de pessoas.

Como meio de fascínio que é, o cinema será, com efeito, utilizado eficazmente para a propaganda ideológica sobre as massas. "De todas as artes o cinema é para nós a mais importante" - esta declaração de Lenine ${ }^{14}$ é sintomática deste novo paradigma que vai entrecruzar intimamente cinema e poder.

No contexto da propaganda política, importa aqui referir que uma das categorias implicadas na caracterização dos regimes antiliberais e antidemocráticos que assolaram a Europa no período entre guerras é a do mito da criação do "homem novo", estreitamente correlacionado com o conceito de "fascismo" mas também com o de "totalitarismo", na medida em que "implica uma invasão e interferência 'totais' da esfera política na privada para cumprir um pretenso objectivo de 'engenharia social"'. ${ }^{15}$ Suportada por Roger Griffin, autor de The Nature of Fascism (1991), relativamente à especificidade do caso português no quadro da "Era das Ditaduras", Irene Pimentel chama-nos a atenção para o seguinte:

Segundo a definição ideal-típica de fascismo elaborada por Roger Griffin, a ideologia fascista seria um 'ultranacionalismo populista palingenético' - palin (restauração); genesis (criação, nascimento) -, cujo mínimo denominador comum seria precisamente o mito da criação do 'homem novo'. Diga-se, porém, que, segundo este autor, a realidade esteve longe do ideal-tipo e que, no caso concreto de Portugal, o regime salazarista teria sido apenas 'parafascista'. ${ }^{16}$

Tal como Luís Reis Torgal afiança, ${ }^{17}$ fazendo jus à sua feição assumidamente "original" no quadro dos regimes autoritários europeus coevos, muito em virtude da sua convergência com a ideologia católica (e do subsequente repúdio da perseguição anti-semita pelos nazis), o Estado Novo cedo se afasta de um carácter "totalitarista" do Estado violento para adoptar um papel mais "paternalista", ainda que forte e intervencionista. Este facto faz com que alguns autores levantem mesmo reservas sobre a adequação da designação 
"fascista" ao regime do Estado Novo em Portugal. ${ }^{18}$ Tal é visível logo pela forma como Salazar sintetiza o conceito de propaganda, fazendo-o confundir-se com o de educação, ao invés da acepção exaltante, agressiva e bélica do fascismo italiano e, sobretudo, do nacional-socialismo alemão: "Sempre que abordei este assunto tenho ligado a propaganda à educação política do povo português e lhe tenho atribuído duas funções - informação primeiro; formação política depois". ${ }^{19}$

Influenciado pela política cinematográfica de Lenine e pelo Departamento V de Joseph Goebbels, cedo António Ferro compreendeu a importância e o poder do cinema. Num discurso proferido em 1946 na festa de distribuição dos Prémios Cinematográficos do SNI de 1944 e 1945, dirá o seguinte:

O Cinema constitui [...] um desses problemas fundamentais, vitais, cuja importância, infelizmente, nem sempre é reconhecida. A sua magia, o seu poder de sedução, a sua força de penetração são incalculáveis. Mais do que a leitura, mais do que a música, mais do que a linguagem radiofónica a imagem penetra, insinua-se sem quase se dar por isso, na alma do homem..$^{20}$

Na sua óptica institucional, constata-se um claro esforço de defesa e orientação da cinematografia nacional. Daí o peremptório apelo do então director do SNI: “Acho [...] que temos o direito, impossível de negar, de defender a nossa personalidade, a nossa moral e até a nossa estética de vida [...]. Protejamos, sim, na parte que nos interessa, o cinema português". ${ }^{21}$ Porém, Salazar não parecia dar a este meio a relevância de que carecia ou merecia. Tal encontra-se logo patente numa afirmação de 1932: "As grandes obras constroem-se no silêncio, e a nossa época é barulhenta, terrivelmente indiscreta. Hoje não se erguem catedrais, constroem-se estádios. Não se fazem teatros, multiplicam-se os cinemas. Não se fazem obras, fazem-se livros. Não se procuram ideias, procuram-se imagens". ${ }^{22}$

\section{4. 'Comédia à portuguesa' e propaganda indirecta}

1933. $O$ ano da institucionalização do Estado Novo coincide ${ }^{23}$ com as filmagens de A Canção de Lisboa, primeiro filme sonoro inteiramente realizado em Portugal e precursor da comédia como género cinematográfico mais popular nas décadas seguintes. ${ }^{24}$

O que se convencionou chamar de "comédias à portuguesa" constitui a produção do período salazarista mais explicitamente vocacionada para o entretenimento, ${ }^{25} \mathrm{e}$ por isso também "a mais ambígua, complexa e impura" ${ }^{26}$ em razão de ser marcada pela contaminação de outras formas de espectáculo, como o Teatro de Revista, ${ }^{27}$ e pela sua relação privilegiada com as indústrias da cultura, em particular, a rádio e a indústria fonográfica. Se, por um lado, se poderá afirmar que o cinema enquanto média de representação "constrói e representa quadros de realidade através da utilização de códigos, convenções e ideologias conhecidos e reconhecidos socialmente", ${ }^{28}$ por outro, para além das análises que não raras vezes sublinham a 'sintonia', a 'coincidência tácita' e os 'ecos' que se estabelecem entre os filmes e a ideologia do Estado Novo, ${ }^{29}$ as suas personagens estão muitas vezes a "contracorrente" de um conjunto de figuras ideais do 'mundo fantasiado' pelo salazarismo, "povoado de cidadãos respeitadores da autoridade e das hierarquias". ${ }^{30}$ Tal explica-se pelo facto de serem escassos os exemplos de filmes de fiç̧ão da iniciativa do próprio regime ${ }^{31}$ ou explicitamente de propaganda política, ${ }^{32}$ já que apenas dois filmes são incluídos pelos especialistas nessa categoria. ${ }^{33}$ Com efeito, à imagem do que ocorre em outros regimes autoritários, como na Itália fascista, na 
Alemanha nazi ou na Espanha franquista, a propaganda passava sobretudo através do documentário, o "cinema real" que procurava divulgar as realizações de Salazar e os grandes acontecimentos da vida cívica, política e cultural do Estado Novo.

Não obstante, importa notar que, submetida às leis de mercado e seguindo a orientação de Joseph Goebbels (ministro da Propaganda do Terceiro Reich, que valorizava a produção de filmes de propaganda indirecta), a maior parte da produção cinematográfica nazi era dedicada ao "entretenimento", ${ }^{34}$ mediante a produção de filmes aparentemente escapistas, mesmo quando diluíam nos seus enredos alguma conotação político-ideológica no que concerne a temas do foro ético, sexual ou social. Também em Itália, através de fortes investimentos e incentivos, ${ }^{35}$ Mussolini consegue promover um poderoso cinema de entretenimento popular que começou a rivalizar com Hollywood em termos de narrativa e sofisticação estilística. Como a discussão de assuntos contemporâneos era acompanhada por uma vigilante censura, o resultado foi a proliferação de diversões inocentes enquanto fuga da realidade, onde se incluem os glamourosos filmes de telefono bianco ("telefone branco"), tal como são designados os inúmeros melodramas, operetas e comédias de costumes em virtude de os seus enredos se desenrolarem em ambientes elegantes, nos quais o maior representante é, justamente, o telefone branco, "símbolo de status e de elegância ultramoderna". ${ }^{36}$ Tal produção era tendencialmente conservadora, promovendo valores familiares, o respeito pela autoridade, uma rígida hierarquia entre classes, a vida no campo, ou seja, todas as posições perfeitamente alinhadas com a ideologia do regime fascista. De facto, para evitar as limitações impostas pela censura das autoridades fascistas, quando temas potencialmente controversos eram abordados no argumento (por exemplo, o divórcio, à época ilegal na Itália, ou o adultério, punível pela lei italiana coeva), a acção tinha muitas vezes lugar em países (por vezes imaginários) da Europa de Leste, ainda que com personagens italianas.

21 Também em Portugal, apesar de não controlado directamente, o cinema de ficção não foi "independente do poder político". ${ }^{37}$ Condicionado como estava por uma legislação proteccionista, pelos apoios e subsídios estatais, por estratégias de promoção internacional, pela atribuição de prémios, mas sobretudo pela apertada rede de controlo dos serviços de censura, ${ }^{38}$ estes filmes acabavam por "se coadunar com os valores do regime", em concordância com o que Luís Reis Torgal denominou de "ideologia indirecta ou contextual" ${ }^{39}$ Daí que, na esteira de Paulo Jorge Granja, ${ }^{40}$ Tiago Baptista possa referir que, "ironia das ironias", apesar de António Ferro, o director do Secretariado de Propaganda Nacional, ${ }^{41}$ considerar as comédias dos anos trinta e quarenta o "cancro do cinema nacional", ${ }^{42}$ elas acabaram por ser, "com toda a certeza, ideologicamente muito mais eficazes do que os poucos filmes de propaganda que o regime salazarista produziu". ${ }^{43}$ Com efeito, apesar de encorajadas por António Ferro, às vezes financiadas e activamente promovidas pelo regime, as produções de índole histórico-literária (de que Camões, de 1946, da autoria Leitão de Barros, é o exemplo maior), destinadas a educar e promover os altos valores da nação, foram ostensivamente preteridas pelo grande público em favor do género das 'comédias à portuguesa' de influência revisteira, de fácil compreensão e identificação, redundando em estrondosos sucessos de bilheteira e perpetuando-se em peças artísticas e documentais de manifesta identificação e reflexo cultural e social do Portugal do segundo terço de novecentos. A continuada repetição destes filmes, com a fundação da RTP em 1955, tornou-os parte de um imaginário popular colectivo associado à ideia de portuguesismo, conquistando, ao lado dos grandes emblemas pictóricos nacionais (de que José Malhoa é o maior expoente), uma longa e 
continuada filiação iconográfica dentro da cultura imagética nacional. Basta pensar como as suas personagens, temas musicais e chavões se perpetuam no imaginário colectivo português, ao ponto de ter sido muito recentemente produzida uma trilogia de remakes de algumas das mais populares comédias à portuguesa. ${ }^{44}$

Cabe, neste contexto, referir que, à época, estas produções cinematográficas se destinavam sobretudo ao consumo das populações urbanas da pequena-burguesia que enchiam as salas de teatro e de cinema. Por isso é compreensível e até expectável que se inspirassem nos próprios destinatários, confundindo-se com eles, para que pudessem experienciar a "ilusão suprema de se estarem a rever numa criação". ${ }^{45} \mathrm{Ou}$ seja, se quisermos falar aqui de ideologia indirecta ou contextual, da qual ecoam tipos, comportamentos e modelos enquadrados na moral salazarista e veiculados pela propaganda (do pobre mas honrado; do bom pai de família e bom católico; da mãe zelosa; da esposa subalterna e guardadora do lar; da donzela casta, prendada, ideal para casal...), importa, contudo, fazer uma destrinça em relação a uma construção de tipo projectiva que poderemos encontrar em outros processos mais directos e afirmativos de catecismo (ou de heroicização) no tocante ao elogio de cidadãos exemplares e à correspondente condenação de contra-exemplos. Com efeito, as personagens destas comédias, menos rígidas e monolíticas enquanto personificação de ideais e modelos de virtude, apresentam-se mais ambivalentes, despreocupadas e inócuas, com as qualidades e defeitos típicos das gentes vulgares, não raras vezes possuidores de um sábio recurso ao trocadilho fácil, quase brejeiro. Circunstância que desarruma, até certo ponto, alguns quadros e papéis fixados estruturadores da moral e dos valores ligados à família no quadro mental salazarista, mas que, ao mesmo tempo, dá conta, "em estado de gema", dos "valores" e "comportamentos sociais das classes sociais que constituíram a base social de apoio ao Estado Novo". ${ }^{46}$ Neste sentido, não será muito arriscado afirmar que, conivente (senão mesmo cúmplice) com esta cinematografia, o Estado Novo promove, ainda que indirectamente, a naturalização daquilo que, muito antes da sua institucionalização, o povo em larga medida já era: pobre, fatalista, resignado, inculto, carente de liberdade, pouco dado à mobilidade, respeitador das hierarquias, com poucos ou nenhuns hábitos culturais, rural, simples, pouco instruído, conservador, católico e despreocupado. Daí que os realizadores próximos do regime não precisassem de fazer muito mais do que simplesmente reproduzir tipos comuns, figuras que povoam uma vivência colectiva, agora ampliada através de dispositivos de representação essencialmente miméticos; no fundo, bastou criar espelhos ao invés de modelos ideais. Mas, aqui, tais espelhos deveriam ser dirigidos ao que melhor convinha, devolvendo figuras aparentadas a um quotidiano simultaneamente verosímil, familiar e pacificador cuja função, mais do que de agente de "formação" ou de "inculcação", pudesse contribuir despreocupadamente para um "efeito político calmante" ${ }^{47}$ onde o divertimento escapista e o riso se assumissem como os meios mais eficazes para o providenciar.

Porém, recentemente Luís Trindade sugere que, neste contexto, uma separação tácita entre comédia e melodrama é problemática. Filmes como 0 Costa do Castelo, A Menina da Rádio e $O$ Leão da Estrela são, para o autor, "híbridos", pois neles "comédia e melodrama" convivem. ${ }^{48}$ Para Trindade, o "drama romântico" acaba aqui por nunca se "libertar da comédia que o enreda" ${ }^{49}$ contestando assim Bénard da Costa, para quem a sobrevivência e o reinteresse manifestado por estes filmes nas últimas décadas são sinal de revivalismo do Portugal salazarista: 
A relação directa que se tende a estabelecer entre comédia e salazarismo é o resultado de uma deformação da memória social provocada pelo suporte cinematográfico. A comédia, nas suas várias formas teatrais (de que a revista é a mais conhecida), era provavelmente o espectáculo preferido do público lisboeta já desde a segunda metade do século XIX, atravessando todos os regimes políticos do Portugal contemporâneo, ou seja, desde muito antes e até depois da ditadura.

[...] que a moral repressiva do salazarismo está sobretudo presente na dimensão melodramática das narrativas e que a comédia, com as suas raízes teatrais, e apesar de não desobedecer propriamente à ideologia dominante da ditadura, está muito para além dos limites, cronológicos e ideológicos, do Estado Novo. ${ }^{50}$

\section{Análise de sete filmes}

\subsection{Homem - a perseguição e a conquista Mulher (a-): pudor e resistência}

O Pai Tirano (1941) retrata a tempestuosa paixão de Chico Mega por Tatão, ele um caixeiro nos Armazéns Grandella, representado por Ribeirinho, ela uma jovem e elegante empregada da Perfumaria da Moda, encarnada por Leonor Maia. Após ter sido veementemente rejeitado por Tatão durante o pequeno-almoço da pensão onde Chico acabara de se hospedar apenas para ficar mais próximo da sua amada, vemo-lo na cena sequente a protagonizar uma aparatosa perseguição de recorte rocambolesco. Havia alguns instantes Tatão avisara que não queria que nenhum "idiota" a seguisse: "Se algum paspalho se atrever comigo, eu dou-lhe com a mala na cara". Ainda assim Chico vai, tresloucado e sem fôlego, furtivo e oculto, entre desvios e atalhos, só para a ver. Aqui, mais uma vez, ressoa o conhecido arquétipo masculino da perseguição, accionado pelo instinto predador, ancestralmente reservado ao homem.

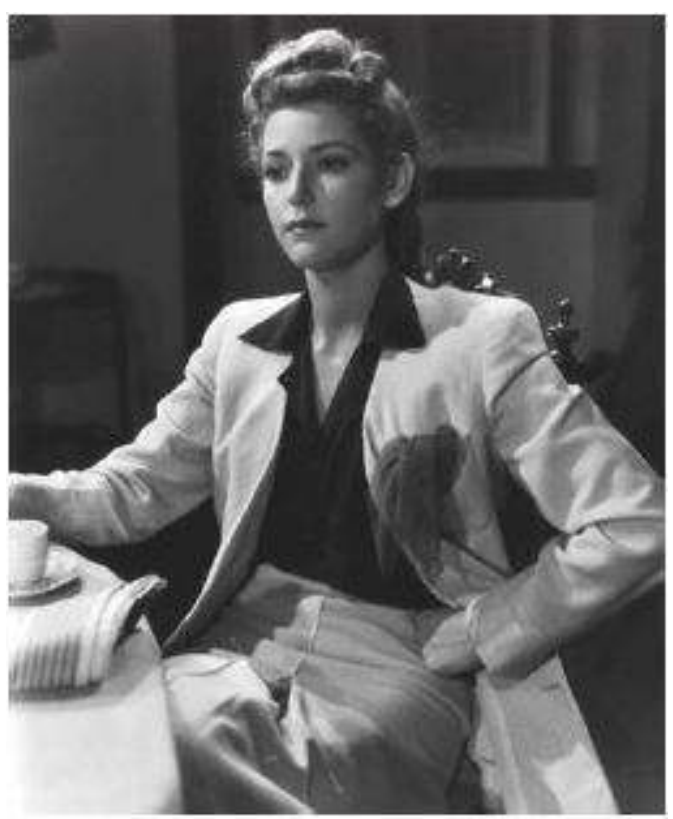

"Se algum paspalho se atrever comigo, eu dou-lhe com a mala na cara". O Pai Tirano (1941), de António Lopes Ribeiro.

Sobre a homologia entre predador/masculino e presa/feminino, Roland Barthes escreve: 
A língua (o vocabulário) estabeleceu desde há muito a equivalência entre o amor e a guerra: trata-se, nos dois casos, de conquistar, seduzir, capturar, etc. Sempre que um sujeito se apaixona, reconduz-se um pouco ao período arcaico em que era costume os homens raptarem as mulheres (para assegurar a exogamia). [...] no mito antigo, o sedutor é activo, quer apoderar-se da presa, é sujeito do rapto (de que o objecto é uma Mulher, como se sabe, sempre passiva). ${ }^{51}$

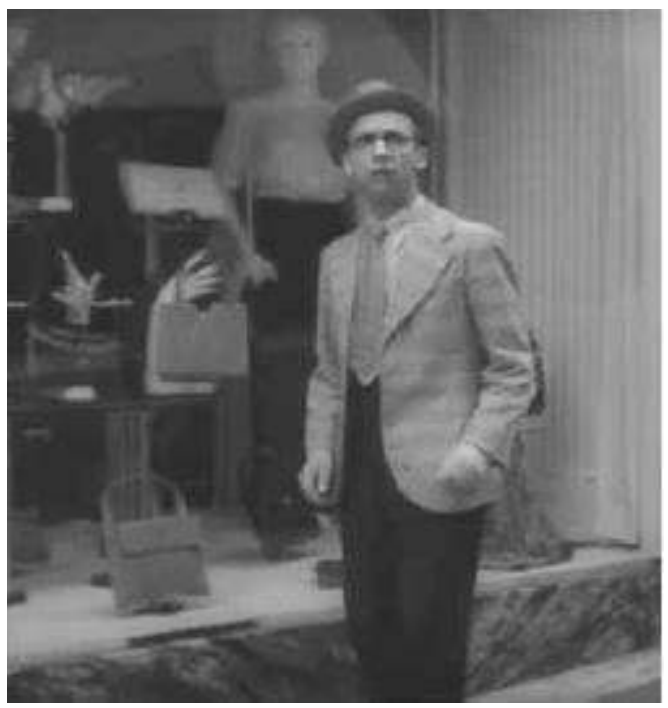

Chico. É ele que avança, que se move e que deseja, e que deseja com uma intensidade mobilizadora. O Pai Tirano (1941), de António Lopes Ribeiro. hado por Fernando Curado Ribeiro) vê pela primeira vez Luisinha uma humilde e simples rapariga numa rua da Baixa lisboeta por onde passava de automóvel, procura de pronto seduzi-la. Após uma longa espera à porta do seu emprego, oferece-lhe uma boleia para casa, mas ela ignora-o. Porém, ele não desiste: ela no eléctrico e ele no automóvel logo atrás, por entre as sinuosas ruas lisboetas, numa perseguição que só termina quando ele toma conhecimento da morada da rapariga. Aqui, a mesma fórmula de $O$ Pai Tirano, mas com uma ligeira nuance: André decide entrar como hóspede na casa onde Luisinha vive, mas desta feita faz-se passar por outra pessoa - diz ser Daniel, um humilde chauffeur que ela não reconhece como sendo o atrevido homem que a abordara na rua. Quando André pergunta, à varanda, se a pode acompanhar até ao miradouro de Sta. Luzia com a sua vizinha Deolinda e o namorado desta, ela não lhe facilita as coisas: "Não sei, vou pensar". E será, então, diante de uma das mais belas vistas nocturnas sobre Lisboa que André se declara: 


\section{LUISINHA: Perdão? De quê?}

ANDRÉ: Porque a princípio a olhei como uma mulher vulgar, que simplesmente se deseja. Mas, hoje que a conheço, e sei quanto é boa e carinhosa, sinto que gosto verdadeiramente de si.

Ainda que se faça passar por uma outra pessoa, é, pois, em nome da "verdade" que André se confessa. Daqui é fácil extrair um sistema de valores que, associando o "vulgar" ao "desejo", opõe este último ao verdadeiro amor, como se de duas entidades antitéticas e inconciliáveis se tratasse. Tal como refere Luís Trindade a respeito destes filmes, "A moral desta história é simples. O amor devia ser distinguido do sexo, a atracção desviada do corpo. Daí o êxito destes corpos assexuados". ${ }^{52}$ Susana Costa Santos corrobora igualmente esta separação tácita acima referida:

o cinema desta época distingue três tipos de amor: o amor verdadeiro, o único aceite socialmente e por isso mesmo recompensado; o amor paixão, perigoso no sentido em que põe em causa a ordem social, e o desejo, permitido ao homem fora da relação conjugal, reprimido e condenado socialmente. É então, o amor verdadeiro, aquele que tem por base a fundação de uma família expresso no casamento, dotando o homem e a mulher de um estatuto social, regido por códigos de conduta definidos (o homem com o papel instrumental, e a mulher com o expressivo), o tipo de amor aceite e incentivado, como forma de preservação da ordem social. ${ }^{53}$

Depois do pedido: "Luisinha, diga-me ao menos que não lhe sou indiferente", ela põe imediatamente um travão em nome da prudência: "Já deve ter notado que também simpatizo consigo, mas há tão pouco tempo que nos conhecemos...". E quando André, que ali se fazia passar por Daniel, um suposto chauffeur, lhe roga que ela acredite nas suas palavras, a desconfiança e a ponderação continuam accionadas: "Mas quem me diz que não modificará mais uma vez o seu juízo a meu respeito?"

O galã de O Pátio das Cantigas (1942) é Carlos Bonito (António Vilar), o "conquistador" que desinquieta as pequenas do bairro, um sujeito que, pela boca de uma das personagens, passa a vida na cama a "cantar tango". A estratégia que Carlos engendra para seduzir Celeste é atirar-lhe um avião de papel pela janela, interrompendo a sua lição de piano. Esta, depois de lhe trocar uns sorrisos, levanta de pronto as armas ante os seus avanços graciosos: "É com essas e com outras que o senhor as leva. Ah, mas a mim não, que não sou dessas. Conheço muito bem a sua reputação". Porém, para nossa surpresa, ela muda abruptamente de expressão dizendo, derretida e sorridente: "um dia há de me ensinar a fazer uma pombinha de papel, sim?", e denotando assim uma certa ambivalência decorrente da frágil fronteira entre recato e amável receptividade, isto é, de quem está dividida entre o estado de alerta e o encanto pelo jogo de sedução que acabará por a enredar nas teias daquele sofisticado sedutor. 


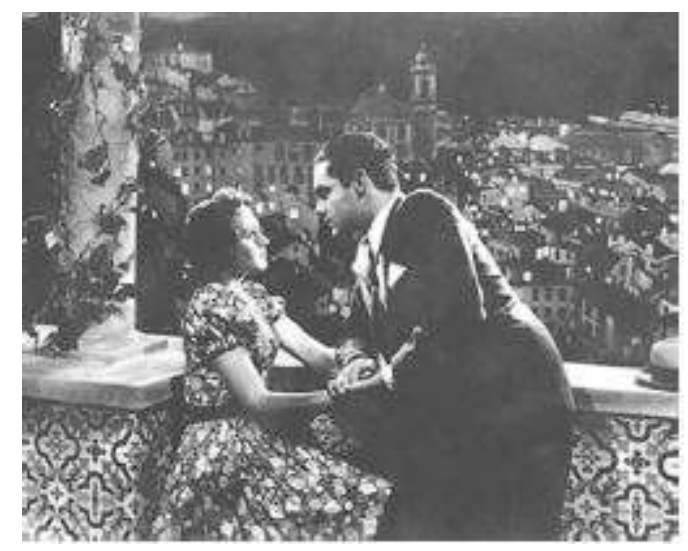

E será, então, diante de uma das mais belas vistas nocturnas sobre Lisboa que André se declara.

o costa do Castelo (1943), de Arthur Duarte. jovens do sexo oposto eram objecto de vigilância apertada. Uma recorrência que vai ao encontro do que Sofia Aboim nos relata: "O namoro era antes de mais uma instituição pública de regras rígidas, a bem da virtude feminina. Controlado pela autoridade paterna e pelo olhar dos parentes e da vizinhança, namorava-se para casar, à soleira da porta ou no interior da casa se a relação fosse aprovada pela família da mulher" ${ }^{54} \mathrm{Em} O$ Costa do Castelo, uma vizinha de Luisinha pede que a acompanhe, como chaperon, num passeio nocturno com o namorado em razão de a sua mãe não os deixar ir "sozinhos"; ao que a segunda imediatamente responde: "Faz ela muito bem!". Um outro exemplo, entre vários que poderíamos citar, é uma cena a este título assaz paradigmática de $O$ Pai Tirano: quando o bon-vivant Artur Castro (Arthur Duarte), fingindo ser solícito, dispensa a companhia da criada Laura (Laura Alves) para, sozinho, levar Tatão a casa, Dona Emília (Emília de Oliveira), madrinha de Tatão, não o consente, dizendo firmemente, em nome da decência e dos bons costumes, que "Não, sozinhos, não!".

\subsection{Homem: o 'galã à portuguesa' - a transgressão e a promiscuidade}

\section{Mulher (b-): a namoradeira e a "moderna" Intriga, troca de parceiros e ruptura amorosa como lugar-comum}

Paira permanentemente sobre o ente masculino um estigma alegre que não é senão o traço característico do mulherengo, do afecto à promiscuidade, como se fosse algo expectável e natural, homólogo à traquinice das crianças. 
Vasco Leitão, o estudante "audaz conquistador das raparigas" de A Canção de Lisboa, magistralmente interpretado por Vasco Santana, não perde uma oportunidade para lançar um flirt à sua jovem vizinha, Maria da Graça. Ele personifica aquele que engana $\mathrm{e}$ ludibria as tias ricas que o suportam com um fictício "consultório riquíssimo" antes mesmo de ser doutor, enquanto nas provas orais da Faculdade faz rir a plateia com graçolas compensando a lição nunca estudada. Porém, é justamente a condição de "cábula", "boémio" e "malandro" aquilo que lhe fornece a sua aura e fascínio. Ele encanta e seduz pela via da palavra, no seu humor transbordante, na sua verbosidade meiga e expressiva. É à janela, enquanto fuma um cigarro, que faz conversas espirituosas com Maria da Graça: "A menina é a vamp do meu pátio. De hoje em diante vou chamar-lhe a Greta Garbo do bairro dos castelinhos." A cena é entrecortada com Alice (interpretada por Beatriz Costa), no andar de baixo, ouvindo a conversa, o que gera tensão no espectador. Após proferir, de forma divertida e eloquente: "Chame-me quando quiser, que eu venho logo ter consigo", Alice desoculta-se abruptamente. Vasco é apanhado pela sua amada a flirtar outra rapariga, pedindo-lhe prontamente explicações: "Com que então, graçolas à vizinha cantadeira? E depois venha cá dizer que eu sou a sua única paixão...”.

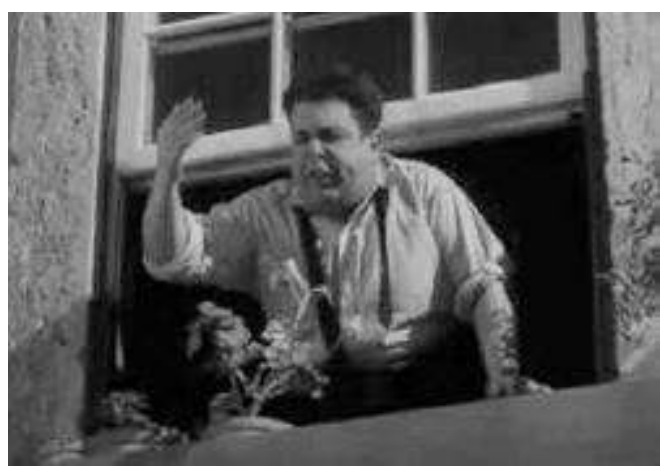

Vasco, à janela, discute com Alice após ter lançado um galanteio a Maria da Graça. A Canção de Lisboa (1933), de Cottinelli Telmo.

Não levando a sério as queixas de Alice, entre o aparato de uma janela que lhe cai na cabeça, o desabafo sobre a vinda a Lisboa das tias abastadas que o sustentam e que não mais conseguirá enganar, Vasco acaba por se esgueirar airosamente invertendo a acusação: faz um enorme inventário dos rapazes com quem Alice supostamente namorara antes dele. Em suma, o estudante doutor 'safa-se', mais uma vez, pela via da eloquência da palavra e do humor, parecendo ser estas as armas infalíveis para contornar (ou compensar) as suas faltas e pecados..$^{55}$

Quanto a Alice, aborrece-se momentaneamente com os atrevimentos do namorado, mas tolera, não rompe logo com a relação. Parece ser sua condição vigiar permanentemente o seu homem. ${ }^{56}$ Este nunca deixa, na ausência do pai, de lhe pedir um "beijinho" e, na ausência desta, de galantear a vizinha.

Da parte das personagens femininas, no que respeita a actos transgressivos, devemos salientar que, ainda que seja a dominante, não figura nestes filmes apenas a jovem donzela, virtuosa, recatada, ideal para casar. Outras tipologias e comportamentos estão ali igualmente representados, pois, ainda que com certos limites, as mulheres também avançam e se insinuam. 


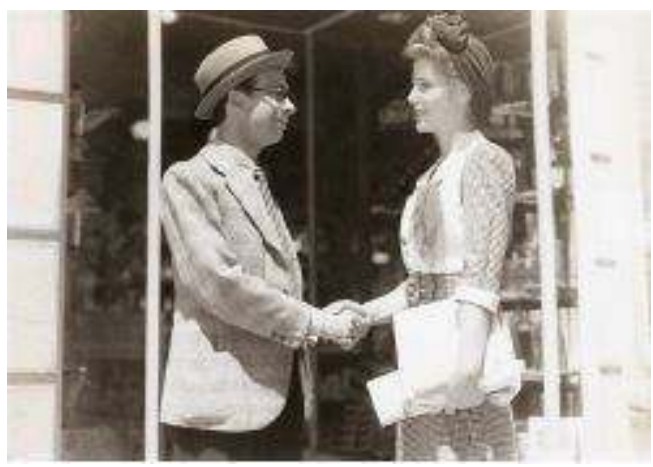

Tatão, assim que lhe chega aos ouvidos que Chico é filho de um fidalgo, o seu comportamento muda. O Pai Tirano (1941), de António Lopes Ribeiro.

Tatão, na película O Pai Tirano, encarna a figura da interesseira. Discordando do desfecho de um filme norte-americano, ${ }^{57}$ durante uma conversa com as colegas da perfumaria, considera que a personagem encarnada por Ginger Rogers fora "tão tola que não casa com um milionário. Prefere um médico que não tem onde cair morto". 0 objectivo de Tatão é claro e assumido ante as outras jovens - "casar com um milionário", em vez de se guardar "para um pelintra qualquer".

Assim que lhe chega aos ouvidos que Chico é filho de um fidalgo, o seu comportamento muda. Vai logo bater à porta do quarto do rapaz, certificando-se primeiro diante do espelho de que o cabelo e a roupa estão bem compostos. Mas Tatão não se fica pela simples presença e aparência. Sim, ela é bonita, esbelta, elegante, supremamente penteada e bem vestida, mas assim que Chico se converte num 'bom partido' ela torna-se amável, prestável, espirituosa; decide até chegar mais tarde ao emprego para privar um pouco com ele ao pequeno-almoço enquanto descreve com humor o seu quotidiano de caixeira. Quando está de saída para o trabalho, contrariando o que havia anteriormente dito, desta vez convida mesmo Chico a acompanhá-la até à porta da loja.

Depois de uma acesa discussão no palacete do seu suposto pai aristocrata (em virtude de este não aceitar que Chico se case como uma mulher de origens modestas), diante de tão contundente prova de amor (numa aparatosa encenação preparada para convencer Tatão, ele optara por ela em detrimento da herança), Tatão regozija-se com a dramática declaração de amor que Chico lhe faz na rua, tendo como pano de fundo um cartaz da peça Amor de Perdição. Mas um amor romântico, "um amor dos antigos" - como ela o apelida -, não é o suficiente para uma rapariga como ela. Criticando a maneira de ser de Chico, as palavras de Tatão reflectem, por via desta espécie de espelho invertido, os principais traços de personalidade que uma rapariga como ela deseja num homem:

... tenho pena que sejas assim tão trombalazana [ingénuo, pateta]. Ainda hoje, com o teu pai, parecias um daqueles meninos piegas que só aparecem no teatro. Agora já não se pode ser como tu és. É preciso ser atrevido. [...] É preciso ter coragem. [...] É preciso não ter medo da vida nem do pai, nem das tias, nem de coisa nenhuma deste mundo.

A par da coragem e da determinação - prerrogativas eminentemente masculinas -, Tatão exige que Chico igualmente se modernize, argumentando que as raparigas do seu tempo já não são o que eram:

Drama, drama, drama! Os dramas já passaram de moda. Tu devias ser um rapaz dos dias de hoje: gostares de cinema, andares sem chapéu, ires aos domingos à praia. Pois nós, as raparigas, já não somos as mesmas. Trabalhamos como vocês, somos independentes, fazemos ginástica, hoje queremos a vida de outra maneira. ${ }^{58}$ 
De notar aqui um perfil psicológico atípico, em virtude de a mulher ocupar, neste caso, um papel "masculino", ou seja, de agente verdadeiramente activo, enérgico e determinado. Tatão atesta a existência de uma considerável margem de liberdade da jovem solteira em relação à mulher casada no tocante à ocupação laboral. ${ }^{59} \mathrm{O}$ impacto da modernidade urbana na vida quotidiana das mulheres portuguesas não pode ser aqui subestimado. Ainda que novas possibilidades não estivessem disponíveis a todas, a figura de Tatão demonstra que novos comportamentos, posturas e hábitos de entretenimento e consumo na esfera pública encontravam-se pelo menos acessíveis a jovens mulheres solteiras na grande cidade, o que permite entrever alguma "independência" (expressa nas suas palavras) e toda uma nova relação com o trabalho e com o lazer (corporalizado, por exemplo, nas suas recorrentes idas ao cinema). Tal poderá levar a supor a emergência de um novo modelo de feminilidade moderna, pequeno-burguesa, urbana e, até certo ponto, laboralmente emancipada, contrastante com a imagem normativa e tradicional da mulher que a moral e a legislação estado-novistas cerceiam de forma tão severa. ${ }^{60}$ Do ponto de vista das limitações que pesam sobre a mulher casada durante o regime de Salazar, Irene Pimental dá-nos conta do seguinte:

As mulheres, que constituíam o «esteio» dessa família tradicional defendida pela ideologia salazarista, tinham sido atiradas pelo regime liberal para o mercado de trabalho onde entravam em concorrência com os homens e por isso, com o novo regime, deveriam regressar ao «lar». Para defender esse regresso à família e a separação de esferas de actuação entre homens e mulheres, Salazar aparentemente valorizou o papel de mãe e de esposa. ${ }^{61}$

Sobre este assunto refere Paulo Jorge Granja que "A mensagem apresentada pela comédia à portuguesa releva, pois, uma oposição firme à 'desmoralização dos costumes' e à emancipação económica e social da mulher veiculadas pela 'modernidade' a que se refere Tatão". ${ }^{62} \mathrm{Em}$ certo sentido, a massificação do cinema, fenómeno da época, está completamente implicada na modernidade, consumismo e cultura de lazer, podendo, à partida, contribuir para um empoderamento da jovem mulher. Como vimos anteriormente, é justamente com referência ao cinema de Hollywood que Tatão demonstra um alargamento de horizontes, um apuramento do sentido crítico e a assunção de novos comportamentos e formas do desejo feminino. É também justamente por isso que, numa óptica nitidamente conservadora, pesa implicitamente sobre ela uma reprovação moral em virtude do tipo de personagem a que ela dá rosto. Na equação entre o 'mau' e o 'bom partido', em matéria de relacionamento amoroso, ela funciona por ora, antes de se redimir no final da estória, como uma espécie de contra-exemplo contrastante com a conduta da jovem mulher ideal para casar: presumida, pretensiosa, materialista, calculista, interesseira, moderna, independente, fascinada pelas stars do cinema norteamericano, excessivamente determinada e emancipada, demarcando-se até do papel tradicional da mulher a favor da diluição das diferenças laborais e sociais entre homens e mulheres. Resumindo, estes acabam por ser, em boa medida, os traços definidores da jovem a evitar. 


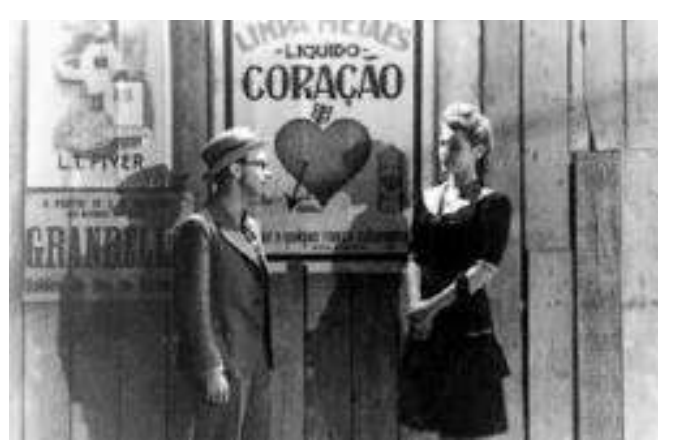

Mas um amor romântico, "um amor dos antigos" - como ela o apelida -, parece não ser o suficiente para uma rapariga como Tatão.

O Pai Tirano (1941), de António Lopes Ribeiro.

A antítese que contrasta com o modelo, anteriormente aflorado, da mulher ideal para namorar e casar encontra-se igualmente encarnada noutros comportamentos e personagens femininas. Por exemplo, Amália, que é, logo ao início da fita $O$ Pátio das Cantigas, apresentada como sendo "bonita mas leviana", faz jus a tal fama quando acaba por confessar ao seu apaixonado, Alfredo, que namorou Carlos (irmão daquele) sem que nunca tivesse gostado dele, assim como havia namorado também "outros homens" pela única razão de ser simplesmente "namoradeira".

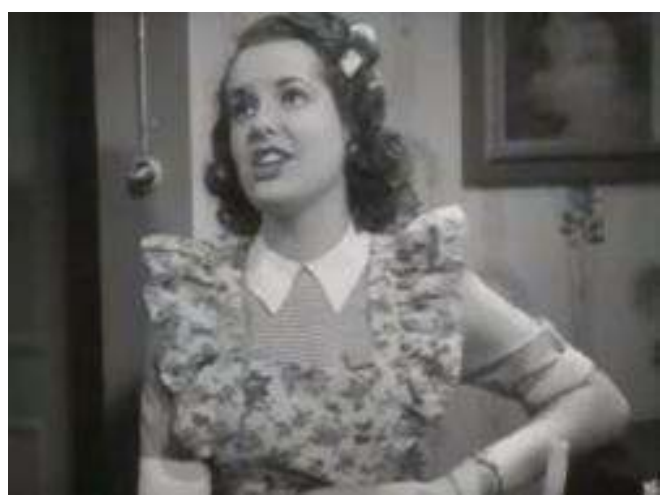

Geninha em A Menina da Rádio (1944), de Arthur Duarte.

Em A Menina da Rádio, Teresinha (Teresa Casal) pede a uma amiga para, fazendo-se passar por Geninha, telefonar a Verdial, a fim de aferir se existe alguma relação amorosa entre ambos ("Telefonas ao Fernando em nome dela e dizes-te perdidamente apaixonada. Que sonhas todas as noites com ele, que não dormes"). Este comportamento encenado é classificado por Verdial diante de Óscar, o noivo da rapariga, como sendo feito de "loucuras, leviandades". Fingindo-se movido pelo "dever de lealdade", na qualidade de "bom camarada", o cantor avisa Óscar do comportamento pouco próprio para uma jovem donzela: "Cuidado, amigo Óscar. [...] Essa menina telefonou-me ontem. E apesar da minha experiência, chocou-me o à-vontade com que me falou [...]. Vê-se que é uma rapariga muito moderna, sem complicações, dizendo o que pensa e não pensando no que diz". ${ }^{63} \mathrm{~A}$ partir desta breve passagem, poderemos muito bem mapear um conjunto de opostos que distinguem o bem do mal no que toca ao ideal de rapariga com quem devemos casar: "o àvontade" é contrário ao recato, à modéstia, ao pudor; ser "moderna" opõe-se à tradição, aos bons costumes, à reverência ante as normas; e "sem complicações" contrasta com os limites de que uma jovem séria deveria estar ciente quando se dirige a um homem. Um exemplo que o corrobora: quando Geninha leva o casaco a casa de Verdial e o porteiro the diz que ela pode subir, ela responde prontamente que "não", preferindo deixar a 
encomenda na entrada do prédio, sabendo que não é próprio de uma rapariga solteira visitar um homem a sós na sua residência. E quando Verdial se desloca então a casa de Geninha para agradecer, aproveitando um momento a sós, pega-lhe na mão em resposta às palavras "espontâneas e vibrantes" que esta putativamente lhe havia proferido ao telefone. Porém, ela levanta-se prontamente, reagindo aos seus avanços e perguntandolhe em tom indignado: "Não quero ouvir mais nada, Sr. Verdial. Que significa a sua atitude?" Cabe, pois, à mulher o papel de guardiã da moral e dos bons costumes, refreando os avanços e atrevimentos dos homens.

No final da película é assim que Fortunato - um pretendente de Geninha que acaba por ver as suas esperanças defraudadas - se vinga, difamando a jovem rapariga junto das senhoras da "velha guarda":

FORTUNATO: Não faz ideia, D. Rosa. Tem sido um escândalo. Primeiro foi com o senhor Óscar. Depois correu com ele e atirou-se ao Fernando. Agora fez as pazes com o Sr. Óscar, mas continua a atirar-se ao Fernandinho por detrás da cortina.

ROSA GONÇALVES: É de ida e volta.

SENHORA 1: Dois namoros. Aos pares? [...]

ROSA GONÇALVES: Pudera, ela açabarca-os! Tal qual como o pai, que também era assim com as mulheres.

SENHORA 1: São as educações modernas, D. Rosa.

emos assim aferir que a interrupção do relacionamento amoroso é um lugar-comum, assim como a intriga e a mudança de parceiro no que aos namoros (e até noivados) diz respeito.

A Canção de Lisboa, em pleno arraial, um jovem aproxima-se da banca das rifas e, dirigindo-se a Alice, lança uma provocação alusiva à compleição física de Vasco:

QUINCAS: Ó menina Alice, ainda tem o hipopótamo?

ALICE: Desse já me livrei, graças a Deus. Agora tenho aqui um urso! - responde a rapariga enquanto aponta para Vasco.

VASCO: Olha lá, ó Quinquinhas, essa do hipopótamo era comigo?

QUINCAS: E se fosse, se calhar davas-me açoites, não?

Para 'roubar' a rapariga de outro, a primeira estratégia é a humilhação pública pela via da chacota e a procura de confronto físico. 0 segundo passo é, aproveitando uma distracção do namorado, fazer sinal para dançar com ela. Esta, para fazer ciúmes e se vingar das transgressões e inúmeros atrevimentos de Vasco, aceita de pronto, piscando o olho e apontando para o namorado, que de nada disto se apercebe. A resposta que vem do lado de Vasco é a de dançar de imediato com outra rapariga. A cena termina com este dirigindo-se a Quincas, que, depois de lhe dizer "Porque é que não bebes água do Vidago, as crianças não bebem aguardente?", lhe disfere uma bofetada em reacção a uma cuspidela. Logo desponta uma zaragata colectiva, apenas refreada com o início do espectáculo de fogo-de-artifício, seguido pela largada dos balões e o início da música das 
marchas. 0 enredo é então dramatizado na própria marcha. Alice, partilhando o mesmo arco com Quincas, canta que "corri com o meu estudante que ficou como uma fera. [...] tenho um gaiato aqui dependurado". Vasco, por seu turno, ladeado por uma rapariga, diz que "não sei com quem ela vai. Cá por mim estou governado com uma outra que eu cá sei...".

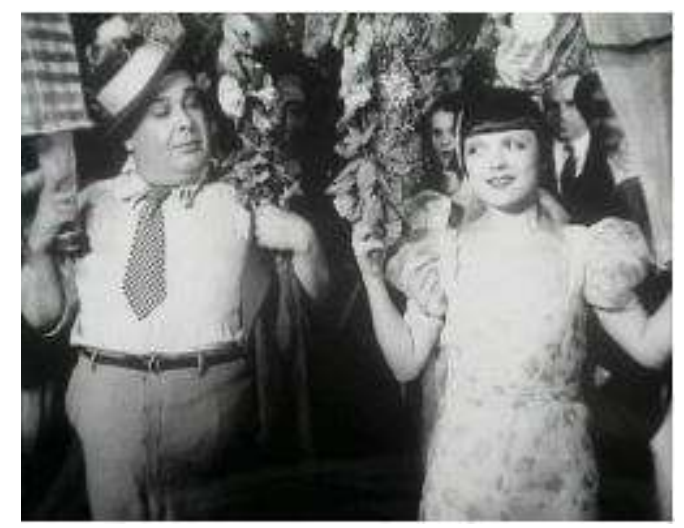

Vasco e Alice em A Canção de Lisboa (1933), de Cottinelli Telmo.

Em síntese, os namorados estão zangados. Na cena seguinte, na cozinha da casa do pai de Alice, a relação termina de forma intempestiva, com pratos partidos no chão e a massa dos bolos espalhada na cara de um do outro. Ou seja, poderemos dizer que estes filmes não só retratam a ruptura amorosa, o fim do namoro e até do noivado, como, por vezes, mostram até uma forte dinâmica no que respeita à troca de par, quer por conveniência socioeconómica, ${ }^{64}$ quer como simples tentativa de desencadear ciúmes no amado ou amada. Não há filme que o retrate melhor do que o Pátio das Cantigas: seduzir ou deixar-se seduzir por outrem é uma forma recorrente de atingir o companheiro/a. Um exemplo paradigmático: a fim de provocar a sua namorada, Amália, o estouvado e soberbo conquistador Carlos Bonito é rápido e cirúrgico no bailarico da festa de Santo António. No momento em que dá um passo de dança com sua nova conquista, diz-lhe: "A Celestezinha levava-me a mal se eu lhe pedisse namoro" (Carlos Bonito). "Não sei porquê! O Carlos é tão bom rapaz" (Celeste). A pergunta e a respectiva resposta repetem-se noutro casal (Susana e Alfredo) para, num terceiro par (a frívola Amália e João Magrinho, interpretado por Barroso Lopes), a ordem de género sofrer uma ligeira variação: "Então porque é que não pede namoro a mim?" “- Está bem! A Amália é tão boa rapariga...”. Em resumo, como se encontra plasmado neste último diálogo, cabe sempre ao rapaz formalizar o pedido de namoro, ainda que seja ela a dar o primeiro passo. De seguida, diante de tão rápida e dinâmica mudança de parceiros, ouvimos uma troca de palavras entre um homem e uma mulher de idade avançada: "Estes rapazes e raparigas são danados. Trocam de namoro como eu troco de camisa...", diz o velhinho, ao que a velhota responde: "Não fale muito alto, porque nós, na idade deles, fazíamos a mesma coisa"; "Ou pior, D. Madalena...", remata o primeiro, lançando uma sonora gargalhada que a sua interlocutora acompanha.

\subsection{Homem: o status económico-social e o dom da palavra Mulher. a beleza como primeira (e quase exclusiva) prerrogativa da condição feminina}

67 O protagonista de A Canção de Lisboa, Vasco Leitão, encarna a desventura típica do galã conquistador que, após viver, com soberba, a situação em que "deixá-las era canja", 
encontra-se, no final, sozinho, embriagado e expulso de um retiro de fado, onde num acto de loucura lançara todos os impropérios contra aquele género musical. Desgraçado, "sem um tostão" e mergulhado num profundo desgosto amoroso causado pela "traidora da franja", Vasco aprendeu por fim a lição quando conhece verdadeiramente o amor e o sabor do sofrimento passional. Tal facto tem sobre ele um efeito transformador. Abandona a carreira de fadista, entretanto fulgurante, e submete-se a um rigoroso exame da Faculdade de Medicina do qual se sai magnificamente com 20 valores, tornando-se, por fim, doutor. Ou seja, logo no primeiro filme que inaugura o género cinematográfico da 'comédia à portuguesa' fica traçado o perfil do galã português (ou 'à portuguesa'): não é pela via do corpo atlético e da beleza física, nem pela personalidade viril, dominadora, misteriosa, grave, expressa em actos grandiloquentes e heróicos, mas antes pelo simples encanto que advém da transbordante comicidade das suas palavras e do carácter trágicocómico (por vezes até patético) da sua conduta. Em termos de personalidade, é o boémio "mandrião" e "mentiroso"; no tocante à compleição física, um rotundo balofo, baixo e atarracado, que usa a cinta das calças quase ao nível do peito. A este respeito Luís Trindade dá-nos uma explicação sobre a "invisibilidade" do corpo masculino português no cinema:

O modelo masculino salazarista era assim, em certo sentido, incorpóreo. Daí a sua pureza, longevidade e legitimidade. O corpo, por natureza corruptível, teve, em semelhante regime moral, de desaparecer. [...] O segredo esteve então na ridicularização. Como se fosse a própria líbido, perante aqueles corpos, a perder a vontade. 0 ridículo mata, diz-se. O de Vasco Santana, António Silva e Ribeirinho matou o desejo. ${ }^{65}$

Esta 'fraca figura', digamos assim, encarna a antítese do galã norte-americano, modelo que aparece, por sua vez, reproduzido nas personagens encarnadas por Manoel de Oliveira (em A Canção de Lisboa), Arthur Duarte (em O Pai Tirano), Curado Ribeiro (em 0 Costa do Castelo e A Menina da Rádio) ou António Vilar (em O Pátio das Cantigas), na maior parte das vezes representando o protótipo do sofisticado conquistador em relação ao qual as donzelas devem tomar precauções.

Resumidamente, quais são os traços de personalidade do protagonista das comédias à portuguesa - daquele que fica com a rapariga no final da história?

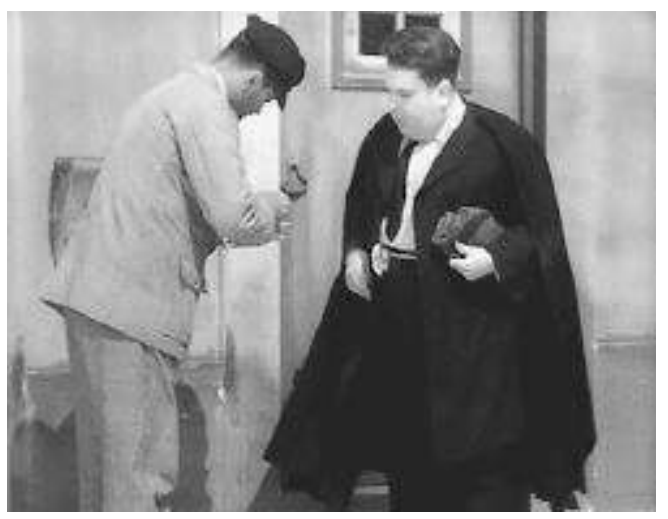

VAsco, O ESTUdANTE "DOUTOR".

A Canção de Lisboa (1933), de Cottinelli Telmo.

70 Afastados dos modelos cosmopolitas e sofisticados do galã hollywoodesco, enquanto sujeito passional, ambos, António Silva e Vasco Santana, representam, com formidável carisma, um tipo inconfundível de português médio, um tanto 'chico-esperto' e aldrabão q. b., mas sempre cheio de um humor contagiante, sabendo adaptar-se habilmente a todas 
as circunstâncias e adversidades. O carácter malcomportado, imoral e subversivo, ainda que apolítico, constitui um dos seus traços mais salientes. Como que compensando a ausência do glamour e dos predicados típicos do herói norte-americano então em voga, no capítulo do humor e dos recursos de linguagem, Silva e Santana chegam a ser exuberantes, inexcedíveis e ostensivos. Já Ribeirinho, esse, por contraste, antecipa a figura do "anti-herói" pós-moderno. A pureza de espírito, a ingenuidade, a modéstia, a pacatez e a falta de auto-estima, no seu caso adapta-se em pleno ao sujeito magricela de baixa estatura que usa óculos, conformado na sua profissão, subalterno e consciente do seu lugar.

O filme O Pai Tirano (1941) começa com um grande plano sobre umas elegantes pernas femininas levemente acariciadas por uma mão masculina insidiosa, ao mesmo tempo que ouvimos uma voz, igualmente masculina, dizendo: "Isto é do melhor que tem aparecido nos últimos tempos". O plano abre-se e percebemos que um vendedor numa sapataria aproveita a sua posição para se deliciar, enquanto vai dizendo à cliente francesa, que atende, que os "portugueses sempre foram os grandes sapateiros". Ou seja, de forma subliminar, podemos dizer que ele 'vende' o produto - os sapatos portugueses - e, por extensão, vende-se a si próprio como potencial amante. Se a cena deixa dúvidas, tal surge confirmado no diálogo que se segue: - "Isto tem que acabar. O Sr. Santana arranja sempre maneira de atender as damas galantes que vêm cá ao Grandela. E eu depois que me aguente com as características" - diz em tom de queixa Chico (Ribeirinho), o mais novo, ao Mestre Santana (Vasco Santana), o mais velho, enquanto este último sorri com ar de malandro. É, pois, o dom da palavra, associado ao timbre e musicalidade, ea forma como esta é eximiamente proferida por Vasco Santana, aquilo que constitui o grande dispositivo de sedução masculino.

Tal como Narciso em O Pátio das Cantigas (aqui novamente interpretado por Vasco Santana), tanto Cipriano Lopes $^{66}$ (homem de solenes e eloquentes discursos) como Simplício Costa $^{67}$ (letrista de temas de fado) - ambos desempenhados por António Silva são excelentes oradores, têm o dom da palavra, fazem versos, são exímios na arte da oratória; eloquentes, produzem discursos ternos, repletos de floreados e de sofisticados recursos poéticos, mas sempre espirituosos e atravessados por um forte sentido anedótico e de comicidade. ${ }^{68}$ No reencontro com Mafalda, Simplício diz-lhe: "Morri para o mundo, para ressuscitar agora, que tornei a encontrar-te"; e, na cena subsequente, enquanto escreve a letra para um fado, é capaz de improvisar rapidamente um verso como este: "Borboleta, quem me dera / E tu, rosa de toucar / Para em plena Primavera / Te enfim poder beijar." Já Cipriano, reacendendo um amor várias décadas adormecido, encanta $\mathrm{D}$. Rosa descrevendo, com impressivo arrebatamento poético, um imaginoso cenário ultraromântico povoado por "Faunos" e "Ninfas" que, por pecar pelo exagero, roça o ridículo, assumindo-se como irónico e caricatural.

Já a mulher, por contraste, denota manifestos cuidados com a sua aparência, constituindo a beleza uma das principais prerrogativas da identidade feminina. 


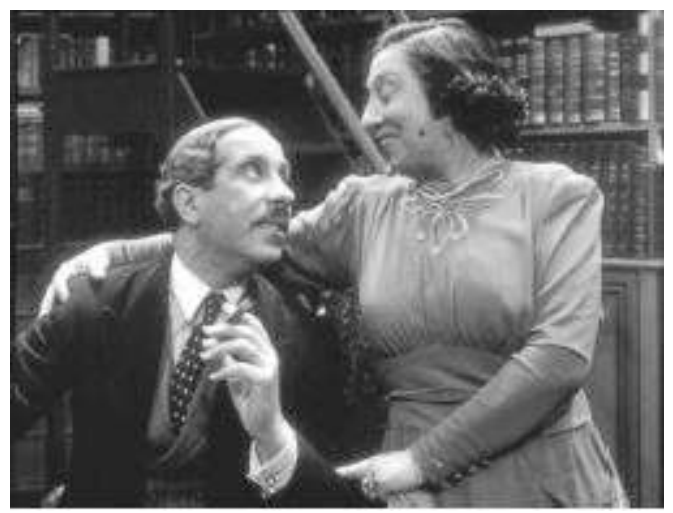

Simplício Costa trocando palavras com Mafalda, em O Costa do Castelo (1943), de Arthur Duarte.

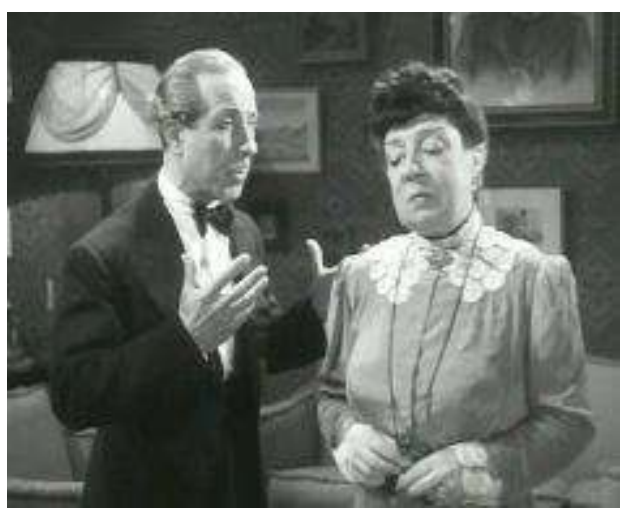

Cipriano, reacendendo um amor várias décadas adormecido, encanta D. Rosa, em A Menina da Rádio (1944), de Arthur Duarte.

Em 0 Costa do Castelo, a apressada Luisinha, quando admoestada pela dona da casa por não tomar o pequeno-almoço, responde em jeito de brincadeira: "Não sabe que a fome é a protectora da elegância?"

75 As mulheres são valorizadas quase exclusivamente pela sua aparência. A personalidade mais do que secundária, pouco ou nada parece importar. Chico, em $O$ Pai Tirano, atesta isso mesmo, quando, diante de um manequim onde momentaneamente parece ver a sua amada, diz para consigo próprio:

É da minha vista ou és a Tatão. Não, não és a Tatão. És um manequim. E afinal a Tatão é também um manequim. Não tem alma, não tem coração, como tu também não tens. Mas é bonita, é elegante e gosta de se vestir bem, como tu também gostas. Tu e ela são iguais.

E não obstante a acusar de não ter "alma" nem "coração", ainda assim Chico remata confessando: "Não posso arrancar cá de dentro esta paixão. [...] Por ti faria todos os sacrifícios".

77 No seu influente texto "Visual Pleasure and Narrative Cinema", ${ }^{69}$ Laura Mulvey afirma que o prazer visual da cultura de massas é, antes de tudo, concebido para se adequar à estrutura psíquica do homem heterossexual, permitindo o seu deleite da imagem feminina enquanto objecto erótico. Segundo a autora, aqui só há lugar para duas posições: a mulher como imagem e o homem como portador do olhar, sendo que Mulvey aponta ainda, neste contexto, para dois modos distintos do olhar masculino na era das personagens femininas de Hollywood entre os anos 1930 e 1960: o voyeurístico (isto é, vendo a mulher 
enquanto imagem para a qual se olha) e o fetichista (vendo a mulher enquanto substituta de uma "ausência" apensa ao complexo de castração).

Ora, os filmes de comédia à portuguesa aqui em apreço só de forma muito contida poderão ilustrar esse paradigma traçado por Mulvey. A este propósito existem apenas duas excepções que, também pela sua assaz subtileza, confirmam a regra. A par da cena de o Pai Tirano acima descrita, protagonizada por Mestre Vasco na sapataria onde este é caixeiro, somente uma outra merece, nesta perspectiva, menção. Em A Menina da Rádio, nos estúdios onde canta um tema romântico, assim que termina a sua performance, Fernando Verdial olha, de forma insidiosa, para uma constelação de pernas femininas, numa objectificação fetichista que o plano focado nas mesmas reforça. Com o propósito de traçar o perfil psicológico da personagem (aludindo à influência do star system estrangeiro coevo, ele é o protótipo da vedeta masculina próxima do galã do cinema norte-americano, habituado a fruir, com misto de soberba e deleite, toda uma multidão de mulheres jovens e bonitas que o acompanham e admiram), tal faz jus, ainda que subtilmente e de raspão, à ideologia do corpo da mulher como espectáculo e objecto de desejo masculino que o cinema noutros contextos então explorava com vincada recorrência.

\subsection{Homem: projecções masculinas da felicidade matrimonial Mulher. a donzela sonha com o dia do casamento}

Importa atender que, tal como Isabel Marques Freire nos dá conta, "Ao longo de 1940 e 1950, a imprensa insiste na publicação de artigos para ajudar as raparigas solteiras e as mulheres casadas a compreender e interiorizar o seu papel de guardiãs da conjugalidade. Delas diz-se depender em primeira e última instância o sucesso e felicidade da vida a dois". ${ }^{70}$

Enquanto João Magrinho (interpretado por Barroso Lopes) faz, em 0 Pátio das Cantigas, uma serenata a Amália, Alfredo e Susana trocam palavras de amor. Vendo em Susana a sua irmã (por quem nutre uma assolapada paixão), Alfredo faz uma idílica projecção da felicidade matrimonial: "Estou a vê-la, muito bonita, muito alegre, numa casita feita para si [...]. E havemos de lá viver muito felizes sem pensar em nada. [...] Quando eu vier do trabalho hei-de vê-la à minha espera". o papel que a mulher ocupa no discurso amoroso masculino pode ser aqui sintetizado da seguinte forma: "numa casita", "bonita", "alegre" e "à espera" que o marido regresse do emprego.

81 De forma lapidar Irene Pimentel dá-nos o retrato da ideologia salazarista no que concerne à função da mulher na sociedade e no casamento:

Com o advento do Estado Novo, a situação da mulher regrediu. Em 1932, em resposta a uma pergunta de António Ferro sobre qual seria o papel destinado à mulher no novo governo e regime, o recém-empossado Presidente do Conselho de Ministros, Oliveira Salazar, afirmou que «... a mulher casada, como o homem casado, é uma coluna da família, base indispensável de uma obra de reconstrução moral» e «a sua função de mãe, de educadora dos seus filhos, não é inferior à do homem». Segundo ele, devia-se deixar «o homem a lutar com a vida no exterior, na rua... E a mulher a defendê-la, no interior da casa». ${ }^{71}$

82 Há uma cena em A Menina da Rádio em que Maria Eugénia e Óscar ensaiam em conjunto pela primeira vez a música que ele havia composto dedicada à sua amada. Intitulada Sonho de Amor, numa das passagens surge a inevitável alusão ao casamento: 
O primeiro sonho / Dos sonhos de amor [...] / Vive dos anseios / Constantes de um lar / Sob alegres bênçãos / Na paz do Senhor / [...] Não pretendo mais que ter / Pequenina casa pois / Onde possamos caber os dois / E se ali como prevemos / Formos três alguma vez / Mais quentinhos viveremos os três.

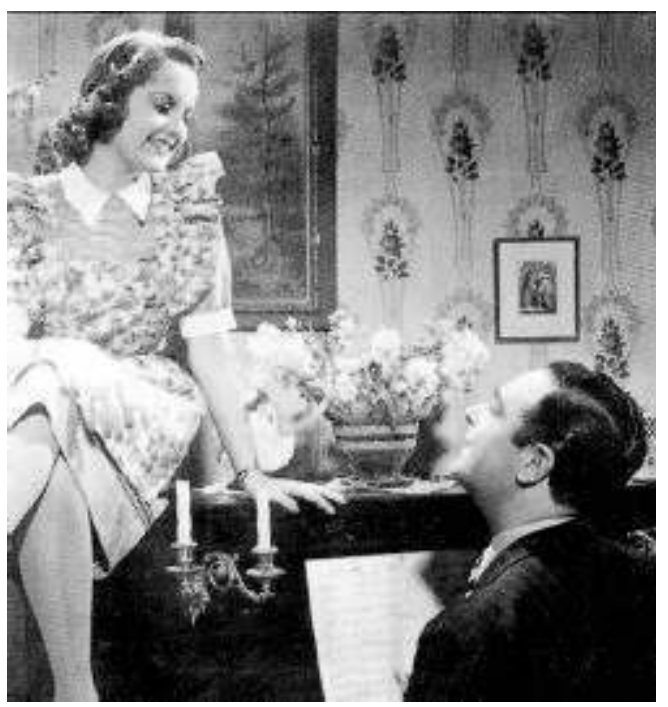

Maria Eugénia e Óscar ensaiam em conjunto pela primeira vez a música que ele havia composto dedicada à sua amada.

A Menina da Rádio (1944), de Arthur Duarte.

Sonho, Casamento, Lar, Deus, Modéstia e Maternidade - são estas as palavras-chave que nos dão acesso à forma como a jovem mulher projecta o seu amor romântico. Significativo aqui é o facto de a letra da música dramatizar os anseios da jovem donzela proferidos na primeira pessoa, ainda que a autoria das mesmas pertençam a um homem, neste caso, o seu noivo. É ele quem, logo em primeira instância, regula o discurso feminino no que aos anseios da companheira diz respeito. A subjectividade feminina está moldada à partida. Ela é a encarnação de um papel que ele definiu e dirige.

\subsection{Homem: os maridos vão às 'meninas'! Mulher. (enquanto) a esposa está confinada aos espaços de domesticidade e ao papel de esposa e mãe}

Em concordância com o quadro de valores do salazarismo, António Silva representa quase sempre o pai, enquanto elemento protector do elemento feminino (curiosamente, nunca é progenitor de rapazes nos filmes). Não obstante os vários traços de mau exemplo, ele é sempre um pai atento, escrupuloso, por vezes um pouco severo e interesseiro (em $A$ Canção de Lisboa); outras vezes, mais benevolente (um verdadeiro cupido entre Luisinha e Daniel em 0 Costa do Castelo). Nas palavras de Paulo Granja, "o paternalismo" surge, assim, nestes filmes como "fulcro da organização social, ao legitimar toda uma hierarquia de poderes que se exercem no sentido descendente e que devem ser respeitados por aqueles que se encontram em posições inferiores, tal como é respeitada a autoridade do pai pelos filhos ao nível da família". ${ }^{72}$

85 A partir da análise conjunta dos argumentos destes filmes, é-nos fácil compreender a existência de um mesmo padrão: justamente aquele que estrutura o dualismo entre o mundo, masculino e instrumental, de fora - o do poder, da autoridade, da transgressão e da acção -, e o mundo expressivo feminino, de dentro - o da casa, do espaço doméstico, 
pautado pelo recato e pela pureza moral, numa configuração fixa que faz sistema com outras dicotomias: cultura vs. natureza, racionalidade vs. irracionalidade, estabilidade vs. instabilidade, independência vs. dependência. Escreve Ana Nunes de Almeida a este propósito: “Aos homens cabem as funções de chefe, provedor e protetor da família que têm ao seu cargo; no recato dos lares, as mulheres (enaltecidas no seu papel de mães), com estatuto subalterno, dedicam-se à lida da casa, à criação dos filhos"..$^{73}$

Não menos importante na construção da individualidade feminina da jovem, o recurso a determinados processos - a maquilhagem, a pose encenada, em cenários caracteristicamente domésticos e com adereços representativos da condição feminina ajuda a construir uma imagem socialmente conveniente, onde não raras vezes a jovem aparece ajudando a mãe (ou empregada) nas tarefas domésticas.

No que toca à privatização do lazer, assiste-se recorrentemente às formas de sociabilidade realizadas no espaço doméstico e que gravitam ora em torno do piano (é o caso de Geninha), instrumento musical que se vulgarizara entre a burguesia mais abastada ${ }^{74}$ ora em torno da audição de programas radiofónicos em casa, isto é, em contexto familiar, auscultando sinfonias, mas sobretudo canções em voga, dando azo a cantores românticos que enchem e inquietam os jovens corações e as fantasias femininas.

A rapariga "certa", "séria", de "boas famílias", a que corresponde ao "bom partido" (são estes os predicados textualmente aplicados), é aquela que se apaixona mas que não se dá rapidamente, que borda, guardada no seu lar, mesmo quando não correspondida ou padecendo de desgostos amorosos; condição que Luisinha, personagem de $O$ costa do Castelo, encarna - sentada, cosendo, ouvindo telefonia e cantando: "Que saudades eu já tinha / Da minha alegre casinha / Tão modesta como eu...".

89 Nestes sete filmes que temos vindo a comentar há apenas duas alusões à relação extraconjugal. Em A Vizinha do Lado, um professor de moral, Plácido Mesquita (Nascimento Fernandes), vem a Lisboa visitar o seu sobrinho Eduardo a fim de o resgatar de uma vida condenável de maus vícios.

O filme põe em acto a correcção de duas situações à época moralmente condenáveis: Eduardo (António Vilar) e a actriz Isabel (Madalena Sotto) vivem juntos sem serem casados, enquanto o Sr. Saraiva (António Silva), devasso e mulherengo, engana continuamente a esposa. Porém, este comportamento adúltero é dramatizado apenas por via da correspondência amorosa trocada com outras mulheres, de que Saraiva, envaidecido, vai dando conta a outros homens com quem priva; mas quando, por fim, reproduzindo as palavras do (falso) moralista Plácido Mesquita ("o casamento é a grande missão do homem sobre a terra"), decide redimir tal conduta levando um ramo de flores à esposa (personagem que nunca chegamos sequer a ver), esta, acabando de receber uma missiva ilícita que o denuncia, recebe-o à porta de casa à bengalada. Ou seja, o adultério, ainda que alvo de condenação e punição, é aqui apenas indiciado à distância; nunca é visto em acto, nem as suas consequências são vividas dentro de casa, isto é, no seio matrimonial. 


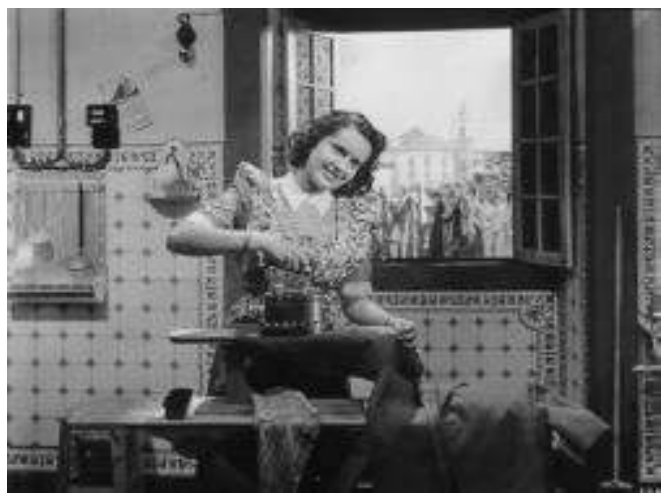

Maria Eugénia, em A Menina da Rádio (1944), de Arthur Duarte.

De notar que em O Leão da Estrela o assunto da extraconjugalidade é objecto de um tratamento deveras diferente, pois uma ida às 'meninas' não merece a mesma condenação que cabe ao adultério. Quando as duas senhoras ficam sozinhas na sala, a anfitriã queixase de o seu marido chegar sempre tarde a casa:

SRA. BARATA: Com o pretexto dos negócios está sempre a jardinar lá por fora... Lembre-se de que há ratoeiras por toda a parte. As mulheres estão muito atrevidas e os homens casados têm muita procura.

SRA. CARLOTA: Tenho ouvido dizer. Mas sabe, o meu Anastácio... (Abana a cabeça)

SRA. BARATA: Querem ver que é uma excepção! [...] Ai, minha filha, não ponha as mãos no fogo.

Numa cena sequente, chamando-o à parte, longe dos ouvidos das esposas, o rico burguês Sr. Barata convida o ferrenho sportinguista da Estrela e modesto manga-de-alpaca Anastácio Silva para um sugestivo passeio pela cidade do Porto relacionado, diz ele, com o "género feminino". o destino é um clube recreativo, onde Barata requisita uma 'chica' para lhe fazer "companhia". Anastácio, empolgado, arregala os olhos quando uma jovem espanhola se junta à mesa onde os dois se encontram. O desfecho é ambos entrarem embriagados num táxi com as duas raparigas. Na manhã seguinte, as duas esposas percebem claramente pelos indícios (entre eles o perfume de mulher) que os maridos tiveram companhia feminina. Tem lugar um jogo do rato e do gato, entre desculpas pouco sustentadas feitas de improviso que denunciam, nas entrelinhas, nitidamente o que se havia passado na noite anterior.

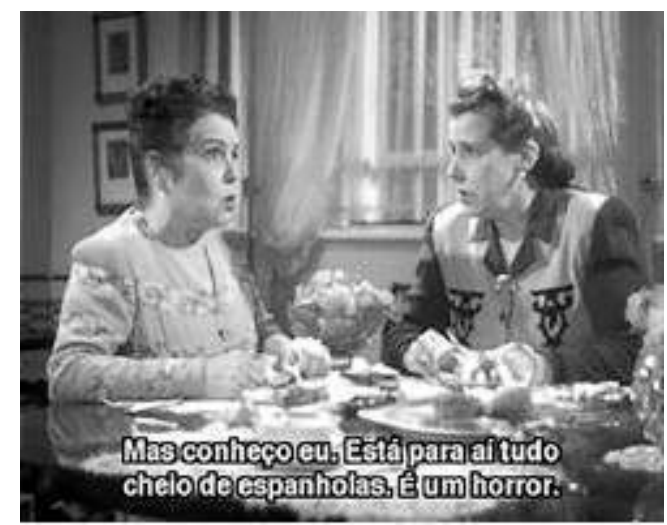

Quando as duas senhoras ficam sozinhas na sala, a anfitriã queixa-se de o seu marido chegar sempre tarde a casa.

O Leão da Estrela (1947), de Arthur Duarte. 
Se, de acordo com os padrões tradicionais e oitocentistas, "a 'domesticidade' era condição 'natural' da mulher", ${ }^{75}$ então percebe-se porque elas ficam em casa enquanto os homens, em conjunto, vão para espaços de diversão nocturna, repletos de jovens espanholas; as espanholas encarnam aqui a "mulher pública", sinónimo de "prostituta", definindo o contra-ideal do que deveria ser uma mulher conveniente: guardadora do lar, ciosa, confinada ao seu espaço e esfera familiar, postada na sua condição de espera, disponível para quando o seu homem regresse, enquanto aos homens são toleradas paixões funestas e prazeres proibidos. É um paradigma que vai ao encontro das palavras de Isabel Marques Freire a respeito de um primeiro momento panorâmico do Estado Novo (1930-1950):

Estamos perante um paradigma utilitário (reprodutivo) da sexualidade, despojado de qualificações hedonistas, mas com alguma margem de exceção. Entre cônjuges tolerava-se uma certa dose (moderada) de prazer sexual, se em causa estivesse o nobre desígnio da fecundação. Os homens tinham ainda uma outra margem de tolerância: a visitação de bordéis (tolerados, regulamentados e inspecionados pela polícia, moralmente censurados, mas indultados pela religião). Nestes contextos paralelos, permitia-se uma maior exploração da sensualidade e erotismo, algum ensaio de fantasias e práticas menos convencionais, que estavam interditas à interação no plateau sexual conjugal. ${ }^{76}$

\section{Considerações finais}

97 A respeito do período que imediatamente se seguiu à institucionalização do Estado Novo, Irene Vaquinhas dá conta do forte intervencionismo do Estado no espaço privado, materializado num sistema de controlo ideológico transversal a todo o corpo social, com especial incidência em áreas fundamentais da socialização como é a família.

O enquadramento legislativo da família é alterado, a qual passa a assentar nos valores da tradição e da doutrina cristã, sendo balizada por dois importantes marcos formais: a Constituição de 1933 e a Concordata assinada com a Santa Sé, em 1940. Rompendo-se com as conceções republicano-liberais, o casamento é considerado inviolável, o divórcio proibido, a família elevada a 'fundamento de toda a ordem política', sendo considerada o núcleo principal de todo o edifício cooperativo e do discurso ideológico do regime. [...] a vida privada é objeto de controlo e de vigilância, o que condiciona a autonomia sexual [...].77

Deste modo se percebe que, no domínio da ficção cinematográfica, a intriga amorosa só tenha lugar antes do casamento: "dar o nó" é sempre o desenlace, o fim da história; para lá do dia da cerimónia, nada sabemos. O matrimónio, sendo sobretudo o 'fim da linha' destas estórias, corporaliza a realização absoluta, definitiva, ocupando, na lógica diegética do argumento, apenas a função de "desfecho ornamental" análogo ao bem conhecido " $E$ viveram felizes para sempre...”. Será também por essa razão que, para além das convenções narrativas e de género, nos argumentos destas comédias poucos casais casados existem. Mesmo entre os veteranos, são poucos ou nenhuns (pois são, ora celibatários, ora viúvos). Em A Canção de Lisboa, as tias ricas de Vasquinho são solteironas, e o alfaiate Caetano vive apenas com a filha, Alice. Em O Pai Tirano, D. Emília e mestre Santana são outros exemplos que igualmente o atestam. Também em A Menina do Rádio, Rosa Gonçalves (interpretação de Maria Matos) é viúva e Cipriano Lopes (António Silva) não tem mulher; porém, apesar de inimigos mortais, no final da trama percebemos que a causa da sua visceral disputa e discordância em torno do advento da rádio não tem por base outra coisa senão um amor secreto antigo entre ambos. Em suma, Cipriano reencontra o amor perdido na mãe do pretendente da filha. Entre os veteranos, esta receita replica-se. Na película O Costa do 
Castelo Mafalda (uma marquesa também interpretada por Maria Matos) e Simplício (um simples Costa do Castelo que António Silva encarna) reatam uma esquecida paixão tinham-se amado na juventude, mas a sua diferença social fez com que fossem separados à força pelos pais. Em A Vizinha do Lado, o professor de moral Plácido Mesquita (Nascimento Fernandes) reencontra na D. Adelaide (Lucília Simões) uma antiga paixão, uma relação fugaz que na juventude não tivera continuidade. Em $O$ Pátio das Cantigas, a relação amorosa entre D. Rosa (uma florista do mercado interpretada por Maria das Neves) e Narciso (um beberrão, mas homem espirituoso e de bom coração, encarnado por Vasco Santana) é 'cármica', pois ficara igualmente irresolvida devido ao facto de ele ter caído no vício da bebida em virtude de o amor que nutria por ela nunca ter sido correspondido - eles apenas estabelecem uma relação, tal como todos os restantes casais, no final do enredo. ${ }^{78} \mathrm{~A}$ excepção, a este título, ocorre em $O$ Pátio das Cantigas. Fazendo jus à sua condição de anti-herói, o intratável e prepotente Evaristo vive somente com a sua filha, a invejosa e mimada Celeste; ele é o único que, no final da estória, se queixa de ficar sem par: "Só, todos dão o nó e eu fico só. Ora, não importa, hei-de rir! [...] Hei-de esmagálos com a minha alegria.". Circunstância que o faz assumir-se como "o eterno viúvo alegre" do Pátio das Cantigas.

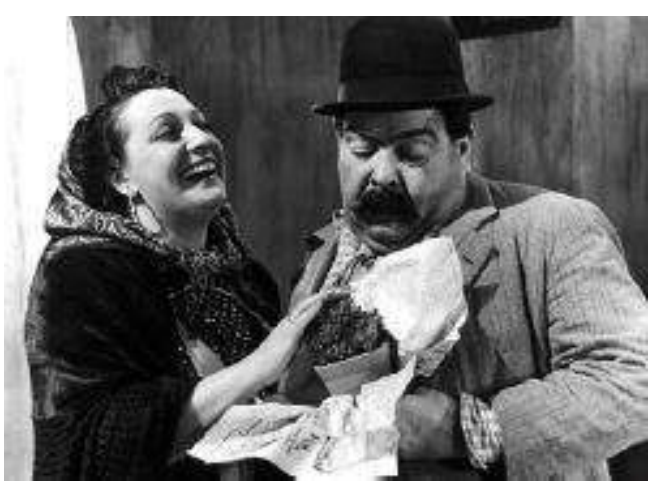

A relação amorosa entre D. Rosa e Narciso ficara irresolvida devido ao facto de ele ter caído no vício da bebida em virtude de o amor que nutria por ela nunca ter sido correspondido.

o Pátio das Cantigas (1942), de Francisco Ribeiro.

Em suma, salvo raríssimas excepções, a "vida em comum" nunca é retratada; apenas o é a fase que a antecede, a saber: a conquista e o namoro. 0 matrimónio é, nestes anos, uma instituição demasiado séria para ser problemática (e problematizada); entidade sagrada, "insolúvel", com a qual não se deve brincar. Garante da estabilidade familiar, ${ }^{79}$ nunca é tema ou questão sobre a qual se pode indagar ou fazer intriga. Só em $O$ Leão da Estrela, onde, ao contrário dos restantes filmes aqui em apreço, o centro da estória já não é a intriga amorosa ${ }^{80}$ mas a conciliação de duas classes sociais (ricos e pobres) ${ }^{81}$ sob o signo do fanatismo clubístico, é que o casamento aparece, e não propriamente como tema ou assunto, mas como simples pano de fundo. Nesse retrato indirecto do matrimónio, dramatizado pelo casal Anastácio (interpretação de António Silva) e Carlota (interpretação de Maria Olguim), não há qualquer dinâmica, evolução diegética ou intriga. Tudo a esse nível aparece como imóvel, tácito, indiscutível, como se se tratasse de uma ordem natural das coisas. O homem é o chefe-de-família, é ele quem trabalha e sustenta a família, enquanto a mulher, na sua condição de "guardiã do lar", permanece em casa, assistida por uma criada e pelas filhas. Ele é a voz que comanda, vivendo a mulher subalterna, tolerando as saídas nocturnas do marido às casas das meninas... 
100 Em que medida poderemos dizer que o apertado regime moral condicionou a representação da manifestação dos afectos e as várias dimensões da intriga amorosa? Num recente texto sobre a censura do cinema português, escreve Leonor Areal:

A colecção de cortes feitos pela censura nos filmes - que o filme de montagem Cinema - Alguns Cortes: Censura (1999), de Manuel Mozos, compila e encadeia - seria suficiente para demonstrar quais as imagens mais temidas pelos censores. Aquelas imagens - entre beijos e outras irreverências carregadas de emoção e significados considerados inadequados [...]. ${ }^{82}$

101 Tudo o que poderia comprometer o casamento, como entidade sagrada, núcleo principal e pilar da estabilidade moral e social, é copiosamente elidido: temas, entre outros, como a luxúria, o prazer sexual, o espaço de intimidade do casal. Leonor Areal, num artigo intitulado "Os tabus do cinema português" (2013), mostra como o cinema português do período do Estado Novo foi vítima directa não só da censura oficial, mas também da censura social, da censura comercial e ainda, e sobretudo, da autocensura resultante daquelas. Assim foram os cineastas encontrando formas de contornar as incontáveis limitações, por meio de processos de alusão e elipse. Entre os assuntos intocáveis elencados pela autora, ${ }^{83}$ encontram-se proibições tácitas no que à sexualidade e ao casamento dizem respeito:

[...] não se podiam fazer histórias de adultério - a não ser que o condenassem claramente e castigassem os prevaricadores, mas são raras as suas aparições [, nem] sugerir comportamentos sexualmente livres, pelo que os filmes de fadistas estão repletos de avisos sobre a sua boa moral. ${ }^{84}$

102 Por isso, o sentido moral ou ideológico do discurso cinematográfico, no que concerne ao relacionamento amoroso, fixava o casamento como único horizonte possível, qual conto de fadas. Não há alternativa possível. A crise no casamento, o fim do amor, a infelicidade entre paredes, a violência doméstica, o desejo por outrem, são tabus que nunca se ousa questionar; pelo contrário, na esfera do sagrado, do intocável, do interdito, encontram-se assim tópicos como a intimidade sexual, o divórcio, o adultério, a sexualidade feminina, a perda da virgindade das raparigas, a violação, o aborto, os filhos bastardos, o incesto, o amor livre, as fantasias eróticas (sobretudo femininas), a luxúria, a perversão sexual, a poligamia, a homossexualidade, etc. Na retórica da elipse, estão os beijos que ficam fora de plano, a ocultação revelando-se paradoxalmente naquilo que ficou por dizer e ver...

$103 \mathrm{O}$ facto é que os argumentos censuram comportamentos atípicos e gestos de transgressão, definidores por excelência do erótico, sobretudo na mulher, enquanto sujeito autónomo e desejante. De acordo com Isabel Marques Freire:

Genericamente, até finais de 1960, organizações do estado, Igreja Católica, família, escola e média convergiam na missão de aconselhar o sexo feminino (mulheres solteiras e casadas) para o escondimento do corpo, o apagamento da sensualidade, a proibição do erotismo e a diabolização do prazer. No seio do matrimónio, a sexualidade feminina estava encerrada dentro de uma espécie de "capelinha» sagrada. Esperava-se que a mulher não reclamasse desejo, e que se refreasse na expressão da excitação sexual. ${ }^{85}$

104 Se, por um lado, a dimensão "disruptiva" é, pela via da comédia, atenuada pelo controlo do Estado Novo, por outro, torna-se manifesto que a condição do boémio conquistador, assim como a ida recorrente 'às meninas', são figuras e comportamentos em boa medida aceitáveis, tolerados e estabilizados pela moral vigente, pois, como Isabel Marques Freire nos dá conta:

Entendia-se que a natureza tinha reservado ao homem um papel ativo (de responsabilidade e protagonismo) no 'ato genésico' (termo comummente usado na 
altura para designar o ato sexual). Tal missão implicava um treino de competências, prévio ao casamento. Mas com quem realizá-lo? Com profissionais do prazer, libertas dos imperativos morais que recaíam sobre as jovens comuns. As experiências masculinas na prostituição capacitavam portanto os futuros maridos. E funcionavam ainda como ritual profilático da heterossexualidade, evitando que os jovens rapazes caíssem em fantasias e experiências homossexuais entendidas como perversas, viciosas e doentias. Para além disso, salvaguardavam a virgem noiva das investidas sensuais do parceiro, antes do matrimónio". ${ }^{86}$

Aqui convém levar mais longe o pensamento de forma a captar a lógica discursiva que se oculta por detrás da linguagem de fiç̧ão. Ora, se tivermos presente que os espaços público e privado se constroem opondo-se, ${ }^{87}$ e que existe uma correlação entre feminino e domesticidade e masculino e espaço público, não é difícil admitir que estes obedecem a princípios contrastantes ${ }^{88}$ nos quais assenta o modelo da conjugalidade institucional proposto por Anália Torres para definir o matrimónio tradicional. ${ }^{89}$ Nesse sentido, como tivemos ocasião de ressaltar, no tocante ao papel que conforma o feminino, ${ }^{90}$ este não pode deixar de traduzir algumas das dimensões mais opressivas do salazarismo: "a moral sexual, a centralidade da família e o lugar da mulher". ${ }^{11}$

A inocuidade do corpo, a consumação do amor na forma de casamento como desfecho ornamental (e assim nunca problemático) do enredo é, portanto, o lugar-comum, em relação ao qual não parece haver escapatória possível. Subsidiários de uma literatura romântica que soube explorar sabiamente esse filão e alimentar sonhos cor-de-rosa de amor e de felicidade eternos, estes filmes devolvem-nos ainda a imagem romanceada em que a mulher é rainha do seu pequeno "castelo", 92 essa espécie de "santuário" ${ }_{93}$ votado ao amor conjugal. A esfera privada do casal é, assim, imaginada como uma espécie de refúgio à margem da vida pública em que a casa é o domínio privado, por excelência, o fundamento material da família, pilar da ordem social.

A análise comparada do enredo dos mais relevantes filmes de 'comédia à portuguesa' faz emergir um paradoxo: por um lado, tido à luz da época como epicentro da vida privada $\mathrm{e}$ unidade primária da vida social e afectiva, o casamento é naturalmente um dos tópicos centrais nessas narrativas - tudo se encaminha para ele como concretização e realização individual. Por isso, nos discursos amorosos, o casamento encontra-se invariavelmente no centro como apoteose e consumação absoluta do amor; a ele está associada a expressão dos sentimentos, lugar por excelência da materialização dos afectos, base da felicidade individual. Porém - salvo raríssimas excepções -, nada dele é retratado. A sua vivência exterior ou social, e sobretudo quotidiana, privada, é elidida, omissa. Tratado dessa forma, ele não é mais do que uma utopia: o círculo da vida comum a dois nunca é invadido pelo espectador. 0 cenário descrito, sempre de forma prospectiva (em juras de amor, poemas, canções e imagens sonhadas), é pródigo em lugares-comuns que desenham, a traço grosso, os elementos que recriam o ambiente do lar do casal, sinónimo de felicidade, onde a mulher é imaginada no aconchego do lar, na tranquilidade mansa do conforto doméstico em ambiente amoroso, onde não há espaço para o mais subtil dos erotismos nem das crises conjugais. ${ }^{94}$ Estes últimos são elementos estranhos e inconcebíveis dentro da constelação daqueles que reconstituem, na ficção cinematográfica, o jardim das delícias da intimidade do casal popular e pequeno-burguês, consubstanciando um 'paraíso' que nunca é dramatizado, a não ser em forma de utopia imaginada, justamente como um belo "sonho cor-de-rosa". 


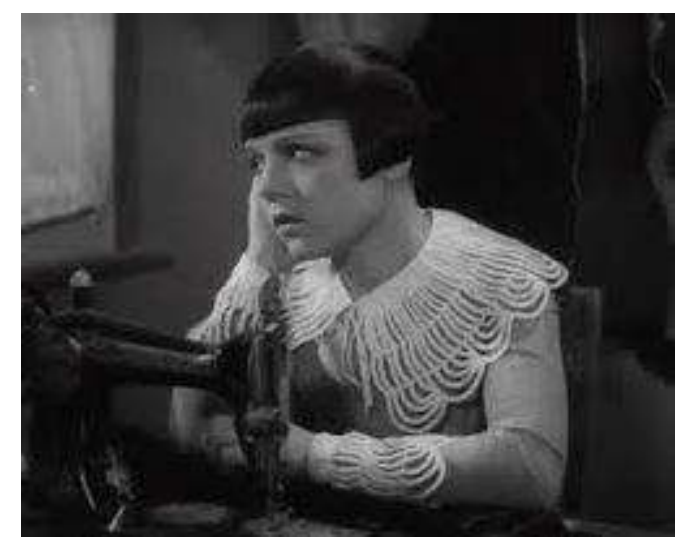

ALICE SONHA COM O dia do SEU CASAMENTO.

A Canção de Lisboa (1933), de Cottinelli Telmo.

Alice, no filme A Canção de Lisboa, passa o tempo entre o trabalho atrás da máquina de costura, tentando sair do jugo protector do pai (ameaçando fugir com Vasco caso o progenitor não aceite o seu namoro), e a vigilância dos atrevimentos do namorado para com a vizinha cantadeira; ao mesmo tempo, sonha com um lindo casamento de conto de fadas que tem como pano de fundo o cenário romântico e idílico dos jardins da Serra de Sintra e do Palácio da Pena.

109 Após a cena do despejo de Vasco por falta de pagamento da renda, vemos Alice na salinha de trabalho junto das meninas-costureiras, materializando esse seu sonho numa canção. A letra da música descreve o que vemos em imagens: "Todas nós temos na vida uma ilusão mais querida... um sonho cor-de-rosa...", e com os olhos fechados, ela imagina-se "a passar entre a multidão" envergando um belo vestido de noiva para seguidamente entrar com o seu Vasco num glamoroso automóvel. Ou seja, é este sonho idílico e romântico, povoado de "pombas lindas às centenas sob o azul do céu", aquilo que alimentava as motivações amorosas da jovem donzela de então.

110 Aos olhos de hoje ${ }^{95}$ - enformados por um modelo de conjugalidade menos institucional do que fusional ${ }^{96} \mathrm{e}$ até associativo, ${ }^{97}$ que concebe o amor como a base da conjugalidade e da escolha amorosa, ao mesmo tempo que atribui à mulher um papel autónomo em paridade com o do homem ${ }^{98}$-, quase podemos detectar nesse tom de exasperação um lampejo de caricatura. Alice é o cúmulo da inocência iludida, doce, frágil, subalterna em relação ao pai, até certo ponto conivente com as travessuras e excessos galanteadores do seu Vasquinho para com a vizinha, mas ainda assim é movida, a todo o momento, por um sonho cor-de-rosa, que não é outra coisa senão o do dia do seu casamento - ainda que reconheça, no final da canção, tratar-se de "um falso real, de uma quimera". 


\section{BIBLIOGRAFIA}

ABOIM, Sofia, "Vidas conjugais: do institucionalismo ao elogio da relação", in ALMEIDA, Ana Nunes (coord.), História da Vida Privada em Portugal (Os Nossos Dias), Lisboa, Círculo de Leitores/ Temas e Debates, Vol. IV, 2011, 80-111.

ALBRECHT, G., Nationalsozialistische Filmpolitik, Stuttgart, Enke, 1969.

ALMEIDA, Ana Nunes, Introdução, in ALMEIDA, Ana Nunes (Coord.), História da Vida Privada em Portugal (Os Nossos Dias), Lisboa, Círculo de Leitores/Temas e Debates, Vol. IV, 2011, 6-14.

AREAL, Leonor, "A censura ao cinema contra o contágio das ideias", in CUNHA, Paulo; BRANCO, Sérgio Dias (Eds.), Atas do III Encontro Anual da AIM, Coimbra, AIM, 2014, 350-359.

AREAL, Leonor, "Os tabus do cinema português", in BAPTISTA, Tiago; MARTINS, Adriana (Eds.), Atas do II Encontro Anual da AIM, Lisboa, AIM, 2013, 340-352.

AREAL, Leonor, Cinema Português - Um país imaginado, Vol. II, Lisboa, Edições 70, 2011.

BAPTISTA, Tiago, "Nacionalmente correcto: a invenção do cinema português", Estudos do Século $X X$, n. 9, 2009, 305-323.

BAPTISTA, Tiago, Nacionalmente correcto: a invenção do cinema português, Lisboa, Edições Tinta da China, 2008.

BARTHES, Roland, Fragmentos de um discurso amoroso, Lisboa, Edições 70, 1995.

BERTETTO, Paolo, "L'immaginario cinematográfico", Enciclopedia del cinema volume I (A-CH), Istituto della Enciclopedia Italiana, Società Italiana degli Autori ed Editori, Roma, 2003, 62-64.

CASCÃO, Rui, “À volta da mesa: sociabilidade e gastronomia”, in MATTOSO, José (Dir.), História da Vida Privada em Portugal (A Época Contemporânea), Lisboa, Círculo de Leitores/Temas e Debates, 2011.

COSTA, João Bénard da, Histórias do Cinema, Lisboa, Imprensa Nacional-Casa da Moeda, 1991.

COVA, Anne; PINTO, António Costa, "O salazarismo e as mulheres. Uma abordagem corporativa”, Penélope, n.. 17, 1997, 71-94.

COVA, Anne; PINTO, António Costa, O Salazarismo e as mulheres: uma abordagem comparativa, Lisboa, Edições Cosmos, 1997.

DIOGO, Vasco, Comédias cinematográficas dos anos 30/40 em Portugal, textos e contextos. Dissertação (Mestrado em Ciências Sociais Cultura e Mudança Social) - Instituto de Ciências Sociais da Universidade de Lisboa, Lisboa, 1996.

FERRO, António, Prémios Literários: 1934-1947, Lisboa, SNI, $1950 \mathrm{~b}$.

FERRO, António, Teatro e Cinema (1936-1949), Lisboa, SNI, 1950a.

FERRO, M. (Dir.), Film et Histoire, Paris, Éd. de l'École des Hautes Études en Sciences Sociales, 1984.

FERRO, M., “Filme: uma contra-análise da sociedade?”, in LE GOFF, J.; NORA, P. (Orgs.), História: novos objetos. Trad.: Terezinha Marinho, Rio de Janeiro, F. Alves, 1976, 202-203.

FREIRE, Isabel Marques, “Intimidade afetiva e sexual no Estado Novo”, Saúde Reprodutiva, Sexualidade e Sociedade, n.. 3, 2013, 56-61. 
FREIRE, Isabel, Amor e Sexo no Tempo de Salazar, Lisboa, Esfera dos Livros, 2010.

GEADA, Eduardo, Os Mundos do Cinema, Lisboa, Editorial Notícias, 1998.

GILI, J., L'Italie de Mussolini et son cinéma, Paris, Henri Veyrier, 1985.

GRANJA, Paulo Jorge, “A comédia à portuguesa, ou a máquina de sonhos a preto e branco do Estado Novo", in GUIMARÃES, Maria Alice Pinto, Saberes, modas \& pó de arroz: Modas \& Bordados. Vida Feminina (1933-1955), Lisboa, Livros Horizonte, 2008.

JASON, Gary, "Film and Propaganda: The Lessons of the Nazi Film Industry", Reason Papers 35, no. 1 (July 2013), 203-219.

MARTINS, Adriana, "Ficções no Cinema Português. Um país imaginado", Aniki, vol. 1, n. 1, 92-95, 2014. Disponível em: < http://www.edicoes70.pt/site/sites/default/files/44-197-1-PB.pdf>. Acesso em: 15 Fev. 2015.

MULVEY, Laura, "Visual Pleasure and Narrative Cinema", Screen 16, no. 3 (Fall 1975), 6-18. Reeditado em Feminism and film theory (ed. C. Penley), Routledge, Nova Iorque, 1988, 57-68. NELSON, Richard Alan, A Chronology and Glossary of Propaganda in the United States, Westport, Conn. and London, Greenwood Press, 1996.

PEREIRA, W. P., “Cinema e propaganda política no fascismo, nazismo, salazarismo e franquismo", História: Questões \& Debates, n. 38, 2003, 101-131.

PIÇARRA, Maria do Carmo, Salazar vai ao Cinema II, Lisboa, 2011.

PIMENTEL, Irene Flunser, A cada um o seu lugar: A política feminina do Estado Novo, Lisboa, Círculo de Leitores, 2011.

PIMENTEL, Irene Flunser, História das Organizações Femininas no Estado Novo, Lisboa, Círculo de Leitores, 2000.

PIMENTEL, Irene, “A situação das mulheres no século XX em Portugal (1)”. Disponível em: https://caminhosdamemoria.wordpress.com/2008/07/07/a-situacao-das-mulheres-no-seculoxx-em-portugal-1/ Postado em: 15 Julho 2008. Acesso em: 15 Fev. 2016.

PIMENTEL, Irene, Contributos para a História das Mulheres no Estado Novo - As Organizações Femininas do Estado Novo. A «Obra das Mães pela Educação Nacional» e a «Mocidade Portuguesa Feminina» (1936-1966), tese de mestrado, curso de mestrado de História dos Séculos XIX e XX, secção Século XX, Lisboa, FCSH/Universidade Nova de Lisboa, 1996, policopiado.

PINA, Luís de, A Aventura do Cinema Português, Lisboa, Editorial Vega, 1977.

PINTO, Costa, O Salazarismo e o fascismo europeu. Problemas de interpretação nas Ciências Sociais, Lisboa, Estampa, 1992.

POLICARPO, V., "Sexualidades em Construção, entre o privado e o público", in ALMEIDA, A. N. (Coord.), História da Vida Privada em Portugal (Os Nossos Dias), Lisboa, Círculo de Leitores/ Temas e Debates, Vol. IV, 2011b, 48-79.

PRAVADELLI, Veronica, Classic Hollywood: lifestyles and film styles of American cinema, 1930-1960, Urbana, University of Illinois Press, [2015].

ROSAS, Fernando, "O salazarismo e o homem novo: ensaio sobre o Estado Novo e a questão do totalitarismo", Análise Social, vol. XXXV (157), 2001, 1031-1054.

SALAZAR, A. de O., "Fins e necessidade de propaganda nacional", in SALAZAR, A. de O, Discursos. 1928-1934, Coimbra, Coimbra Editora, 1935. 
SAMPAIO, Sofia, "Recensão de 'Cinema no Estado Novo: A Encenação do Regime', de Patrícia Vieira”, Cinema: Journal of Philosophy and the Moving Image, Lisboa, n. 5, 2014, 226-230.

SANTOS, Susana Costa, "A maçã de Eva: formas de conjugalidade no cinema português contemporâneo", in Actas do Colóquio Internacional Família, Género e Sexualidade nas Sociedades Contemporâneas, Lisboa, Associação Portuguesa de Sociologia, 2002, 133-148.

SILVA, Manuel Deniz, “Cinema no Estado Novo”, Aniki, vol. 1, n. 2, 357-362, 2014. Disponível em: <http://aim.org.pt/ojs/index.php/revista/article/view/78/html>. Acesso em: 14 Fev. 2015.

SMITH, Bruce L., Propaganda. britannica.com. Encyclopædia Britannica, 2016. Disponível em: https://www.britannica.com/topic/propaganda.

TANNENBAUM, E. R., La experiencia fascista. Sociedad y cultura en Italia (1922-1945), Madrid, Alianza Editorial, 1975.

TORGAL, Luís Reis (Org.), o cinema sob o olhar de Salazar, Lisboa, Círculo de Leitores, 2001, 194-233.

TORGAL, Luís Reis, “Cinema e Propaganda no Estado Novo”, Revista de História das Ideias, Coimbra, v. $18,1996,277-337$.

TORRES, Anália, “A individualização no feminino, o casamento e o amor”, in PEIXOTO, Clarice Ehlers; SINGLY, François; CHICCELLI, Vicenzo (Orgs.), Família e Individualização, Rio de Janeiro, Fundação Getúlio Vargas Editora, 2000.

TORRES, Anália, “Amores e desamores - para uma análise sociológica das relações afectivas”, Sociologia: Problemas e Práticas, n. 3, 1987, 21-33.

TORRES, Anália, Divórcio em Portugal, Oeiras, Celta Editora,1996.

TORRES, Anália, Trajectórias, dinâmicas e formas de conjugalidade, assimetrias sociais e de género no casamento". Dissertação (Doutoramento em Sociologia), ISCTE - Instituto Universitário de Lisboa (ISCTE-IUL), Lisboa, 2000.

TRINDADE, Luís, "Riso Desdramatizador: Combate de Géneros e as Memórias do Cinema Clássico Português", Portuguese Cultural Studies, Vol. III (ed. Paula Jordão), 112-125, 3 Spring 2010. Disponível em: <http://www2.let.uu.nl/solis/psc/p/VolumeTHREE.htm>. Acesso em: 12 Fev. 2015.

TRINDADE, Luís, “Sexualidade e masculinidade na comédia à Portuguesa”, in REZOLA, Maria Inácia e OLIVEIRA, Pedro Aires (Coord.), o Eterno Retorno. Estudos em Homenagem a António Reis, Lisboa, Campo da Comunicação, 2013, 165-172.

TRINDADE, Luís, Fotobiografias do Século XX - António Silva, Lisboa, Círculo de Leitores, 2002. TRINDADE, Luís, Fotobiografias do Século XX - Vasco Santana, Lisboa, Temas e Debates, 2009. TRINDADE, Luís, O Estranho Caso do Nacionalismo Português. O Salazarismo entre a literatura e a política, Lisboa, Imprensa de Ciências Sociais, 2008.

VAQUINHAS, Irene, Introdução, in VAQUINHAS, Irene (Coord.), História da Vida Privada em Portugal (A Época Contemporânea), Lisboa, Círculo de Leitores/Temas e Debates, Vol. III, 2011, 6-20.

VIEIRA, Patrícia, Cinema do Estado Novo - A encenação do Regime, Lisboa, Colibri, 2011.

A CANÇÃO DE LISBOA. Dir. Cottinelli Telmo. Argumento: Cottinelli Telmo. Portugal: Tobis Portuguesa, 1933. pb. $85 \mathrm{~min}$.

O PAI TIRANO. Dir. António Lopes Ribeiro. Argumento: António Lopes Ribeiro. Portugal: Produções António Lopes Ribeiro, 1941. pb. 114 min. 
O PÁTIO DAS CANTIGAS. Dir. Francisco Ribeiro (Ribeirinho). Argumento: Vasco Santana.

Portugal: Produções António Lopes Ribeiro, 1942. pb. 105 min.

O COSTA DO CASTELO. Dir. Arthur Duarte. Argumento: Fernando Fragoso e João Bastos. Portugal: Tobis Portuguesa, 1943. pb. $135 \mathrm{~min}$.

A MENINA DA RÁDIO. Dir. Arthur Duarte. Argumento: João Bastos. Portugal: Tobis Portuguesa, 1944. pb. $106 \mathrm{~min}$.

A VIZINHA DO LADO. Dir. António Lopes Ribeiro. Argumento: António Lopes Ribeiro (adaptação da peça teatral de André Brun). Portugal: Companhia Portuguesa de Filmes, Sociedade Portuguesa de Actualidades Cinematográficas (SPAC), 1945. pb. 115 min.

LEÃO DA ESTRELA. Dir. Arthur Duarte. Argumento: João Bastos, Félix Bermudes e Ernesto Rodrigues. Portugal: Tobis Portuguesa, 1947. pb. $121 \mathrm{~min}$.

\section{NOTAS}

1. Cf. VIEIRA, 2011. Em Cinema no Estado Novo: a encenação do regime, Patrícia Vieira mapeia de forma sistemática os temas presentes no corpus de longas-metragens de ficção realizadas entre os anos 30 e 50 em Portugal, procurando estabelecer a sua filiação com a ideologia do regime. Não obstante a intuição e poder interpretativo assinalável, tal estudo mereceu duras críticas por parte de Manuel Deniz Silva e Sofia Sampaio: “[...] o livro confunde sistematicamente o regime do Estado Novo com a retórica do seu líder. A ditadura não nos é apresentada enquanto realidade histórica, enquanto processo político e social atravessado por contradições e negociações complexas, mas sim como uma lógica unicamente discursiva, um conjunto de enunciados invariavelmente provenientes do centro do poder" (SILVA, 2014, p. 360); "Os filmes não têm precedência sobre as ideias (nem as do regime nem as da autora), cabendo-lhes maioritariamente um papel de ilustração dessas ideias. A especificidade do meio cinematográfico não é identificada, muito menos explorada, favorecendo conexões e leituras algo forçadas" (SAMPAIO, 2014, p. 229).

2. POLICARPO, 2011b, p. 49.

3. FERRO, 1976.

4. VIEIRA, 2011, pp. 19-20.

5. PIMENTEL, 2000, p. 29.

6. PIMENTEL, 2008, s/p.

7. COVA e PINTO, 1997, p. 72. A homologia entre a arte de gerir a casa e a de gerir o Estado surge patente na publicação "Economia Doméstica", lançada em 1945, pelo Secretariado de Propaganda Nacional. Gerir e organizar o lar doméstico parece ser uma ciência que exige método e rigor. Daí a criação de alguns cursos de ensino doméstico e, por exemplo, da Escola Técnica de Formação de Donas de Casa, uma iniciativa da revista "Eva". Cf. Revista "Eva", Abril de 1945, pp. 26-52.

8. GUIMARÃES, 2008, p. 87.

9. A encíclica Rerum Novarum enunciava a primazia e anterioridade da família relativamente à sociedade civil. Cf. COVA e PINTO, 1997, pp. 72-73.

10. FREIRE, 2013, p. 58.

11. SANTOS, 2002, p. 143.

12. De acordo com Bruce L. SMITH, "Propaganda is the more or less systematic effort to manipulate other people's beliefs, attitudes, or actions by means of symbols (words, gestures, banners, monuments, music, clothing, insignia, hairstyles, designs on coins and postage stamps, and so forth)" (SMITH, 2016).

13. Cf. SMITH, 2016.

14. Cit. por GEADA, 1998, p. 85. 

15. PIMENTEL, 2011, p. 17.
16. PIMENTEL, 2011, p. 17.
17. TORGAL, 2008, p. 33.
18. Cf. PINTO, 1992; ROSAS, 2001.
19. SALAZAR, 1935, p. 195.
20. FERRO, 1950a, p. 44.
21. FERRO, 1950a, p. 46.
22. SALAZAR, 1932, apud FERRO, 1941, p. 217.

23. Refere Luís Trindade a este propósito que "Regime político e indústria de cinema partiam então simultaneamente para uma posteridade duradoura. Parte das suas formas de legitimação assentou na afirmação de uma identidade nacional contra as ameaças externas. Se o salazarismo começou por ser, antes de mais, um anticomunismo, já o cinema português procurava uma forma de rivalizar com Hollywood" (TRINDADE, 2013, p. 165).

24. Cf. GRANJA, 2001, p. 196.

25. "Muitos destes filmes foram enormes êxitos de bilheteira e, nos últimos trinta anos, tiveram uma segunda vida importante através de repetidas exibições na televisão e de várias edições em vídeo e dvd. Esta segunda vida atribuiu-lhes, retrospectivamente e numa altura em que a reputação dos filmes portugueses atravessava o seu período mais baixo, o estatuto de contraprova de que podia existir um'cinema português popular'. Com tudo o que essa retrovalorização possa ter de revanchista, não deixa de ser decepcionante que tenha sido já em democracia que filmes social e politicamente tão conservadores tenham logrado reunir tamanho consenso cultural" (BAPTISTA, 2008, p. 5).

26. SILVA, 2014, p. 358.

27. Cf. PINA, 1977, p. 86.

28. SANTOS, 2002, p. 134.

29. Cf. SAMPAIO, 2014, p. 229.

30. SILVA, 2014, p. 358.

31. Para Luís Reis Torgal apenas existem dois filmes "políticos" em Portugal neste período: A Revolução de Maio (1937) e o Feitiço do Império (1940), ambos realizados por António Lopes Ribeiro. São obras claras de propaganda política estado-novista, quer a nível dos enredos, quer no que às questões financeiras diz respeito, uma vez que foram patrocinadas pelo SPN e pela Agência Geral das Colónias, respectivamente, contando ainda com apoio de outros organismos estatais, como o Comissariado do Desemprego (TORGAL, 1996).

32. Cf. TORGAL, 1996; VIEIRA, 2011, p. 19.

33. No cruzamento de projectos estéticos e políticos nem sempre coincidentes, pergunta com justeza e propriedade Manuel Deniz Silva: “Até que ponto não foram estes filmes um resultado da fabricação pelos próprios agentes cinematográficos de ficções políticas próprias dentro do universo ideológico da ditadura? [...] E como é que elas integraram ou se diferenciaram dos modelos cinematográficos internacionais, que desde sempre marcaram a imaginação cinéfila nacional?" (SILVA, 2014, p. 362).

34. ALBRECHT, 1969, pp. 96-97.

35. Cf. TANNENBAUM, 1975, p. 311.

36. PEREIRA, 2003, p. 107, nota 12.

37. VIEIRA, 2011, p. 18.

38. Cf. ANTÓNIO, 1978; AREAL, 2013 e 2014.

39. TORGAL, 2000, p. 19. "Mesmo ao nível das comédias, onde não se encontra nitidamente plasmada uma ideologia, é legítimo considerar que está implícita uma 'contra-imagem' da sociedade". Por outras palavras, o cinema é uma forma de lazer "que faz parte de todo o processo histórico" (TORGAL, 2000, p. 17), podendo dessa forma camuflar as graves tensões da sociedade, neste caso, ao nível da vida privada e dos costumes. 
40. GRANJA, 2001, p. 196.

41. “[...] não podemos esquecer que [...] foi o primeiro director do SPN um intelectual que bem cedo se interessou pelo fenómeno cinematográfico, António Ferro, e que por isso deveria procurar mobilizar este meio para a propaganda do regime" (TORGAL, 2001b, p. 67).

42. Ao contrário dos filmes 'históricos', entendia António Ferro que as comédias eram (para empregar as suas expressivas palavras) «o cancro do cinema nacional, afora duas ou três excepções» (FERRO, 1950, pp. 64-65). Uma dessas excepções seria, com certeza, O Pátio das Cantigas (1942), da autoria do irmão de António Lopes Ribeiro, Francisco Ribeiro («Ribeirinho»), que foi director do 'Teatro do Povo', organizado pelo SPN” (TORGAL, 2001a, p. 24). As outras duas produções serão do próprio António Lopes Ribeiro, o produtor-realizador oficioso do regime, designadamente O Pai Tirano (1941) e A Vizinha do Lado (1945), tendo esta última mesmo recebido o Grande Prémio do SNI - 1945.

43. BAPTISTA, 2008, p. 5.

44. Novos Clássicos (também conhecida por Os Novos Clássicos Portugueses) é uma trilogia de filmes e mini-séries portugueses do género comédia, realizados por Leonel Vieira e Pedro Varela, escritos por Pedro Varela e Tiago Santos e produzidos por Leonel Vieira. A trilogia consiste em O Pátio das Cantigas (2015), O Leão da Estrela (2015) e A Canção de Lisboa (2016). Versões alongadas destes filmes foram editadas em formato mini-série, para serem transmitidos pela RTP.

45. TRINDADE, 2002, p. 10. A este propósito escreverá João Bénard da Costa que "A ficção que encenavam era a sua verdade. Verdade deles e verdade desses filmes, na grandeza da encenação e na pequenez do encenado" (COSTA, 1991, p. 71).

46. GRANJA, 2000, pp. 196-197.

47. TRINDADE, 2002, p. 10.

48. TRINDADE, 2010, p. 115.

49. TRINDADE, 2010, p. 122.

50. TRINDADE, 2010, pp. 115-123.

51. BARTHES, 1995, p. 226.

52. TRINDADE, 2013.

53. SANTOS, 2002, p. 143.

54. ABOIM, 2011, p. 84.

55. O galã de O Pátio das Cantigas (1942) é Carlos Bonito (António Vilar), o "conquistador" que desinquieta as pequenas do bairro. Quando este é apanhado, à janela, a "arrastar a asa" a Susana, a irmã da rapariga com quem ele namora, a desculpa é a mesma: "Então não vês que estava a reinar com aquele anjinho?".

56. Em 0 Costa do Castelo, enquanto André da Silveira (o jovem aristocrata desempenhado por Fernando Curado Ribeiro) aguarda à porta do banco pela saída da Luisinha, é subitamente interpelado por uma jovem loura, que lhe pergunta porque este não lhe diz nada há algum tempo e que o avisa: "Vê lá no que te metes. Andas vigiado."

57. Provavelmente trata-se de Kitty Foyle (Kitty Foyle, no Brasil; Kitty, a rapariga da gola branca, em Portugal), filme norte-americano de 1940 dirigido por Sam Wood.

58. Segundo Vasco Diogo, a actividade profissional das mulheres torna-se motivo de tensão entre conservadorismo e transgressão presente em todos os filmes analisados: "se existem mulheres independentes e trabalhadoras (...), também lá estão as filhas submissas e casadoiras, as donas de casa dedicadas, sacrificadas e submissas e as mulheres trabalhadoras das classes mais baixas, dentro de um espectro de profissões legítimas, como costureiras, criadas ou floristas" (DIOGO, 1996, p. 135).

59. Para além de Tatão, devemos sublinhar também neste âmbito os casos de D. Cândida, Gracinha e Amélia, em 0 Pai Tirano; de Amália e Maria da Graça, em 0 Pátio das Cantigas; assim como de Luisinha, Isabel e Rosa Maria, em o Costa do Castelo. 
60. Sobre a condição discriminatória da lei para com a mulher, colocando-a numa vincada condição subalterna em relação ao marido, Irene Pimental dá conta do seguinte: "Os traços discricionários do Código Civil de 1867, atenuados pelo regime republicano, voltaram em força com o Estado Novo. o Código do Processo Civil de 1939 reintroduziu o poder concedido ao marido de requerer a entrega e 'depósito' judicial da mulher casada. Este possibilitava ao marido, em caso de saída da mulher da casa familiar, exigir judicialmente que ela fosse aí compulsivamente 'depositada' em sua casa, como se fosse um fardo. As mulheres deixaram também de poder exercer comércio, viajar para fora do país, celebrar contratos e administrar bens sem o consentimento do marido" (PIMENTEL s/d.).

61. PIMENTEL, 2008, s/p.

62. GRANJA, 2001, p. 222.

63. Este incidente, associado a outro mal-entendido, levará Óscar a romper o noivado com Geninha.

64. No filme $O$ Pai Tirano, quando a farsa em torno da fidalguia de Chico cai por terra diante dos olhos de Tatão, esta de imediato rompe com o namoro e aceita a proximidade de Artur Castro (interpretado por Arthur Duarte), saindo do teatro de braços dados com aquele bon-vivant que há muito vinha cortejando a empregada da perfumaria.

65. TRINDADE, 2013.

66. No filme A Menina da Rádio.

67. No filme $O$ Costa do Castelo.

68. Facto que evidencia bem a origem destes actores, com diálogos vivos e repletos de duplo sentido, num humor ora irónico, ora caricatural, uma das técnicas da revista à portuguesa.

69. MULVEY, 1975, pp. 6-18.

70. FREIRE, 2013, p. 58.

71. PIMENTEL, $\mathrm{s} / \mathrm{d}$.

72. GRANJA, 2001, p. 216.

73. ALMEIDA, 2011, p. 9.

74. VAQUINHAS, 2011, p. 17.

75. VAQUINHAS, 2011, p. 12.

76. FREIRE, 2013, p. 57.

77. VAQUINHAS, 2011, p. 19.

78. "O facto de muitas das personagens masculinas mais velhas serem ou viúvas ou celibatárias facilita a comparação com Salazar. Poder-se-á, obviamente, argumentar que a condição destas personagens corresponde a uma necessidade narrativa, pois o happy end exige que elas acabem por casar - e, de facto, se exceptuarmos Evaristo, que se torna num 'viúvo alegre', e Anastácio Silva, que é já casado, todas as outras acabam por encontrar par” (GRANJA, 2001, p. 215).

79. "A família, fundada no casamento religioso para toda a vida e assente na procriação, é um símbolo da estabilidade institucional da nação, o lugar de transmissão e conservação dos costumes" (ALMEIDA, 2011, p. 9).

80. Tal como notou Luís Trindade, "se olharmos com mais atenção para os argumentos que organizam as narrativas e os situarmos no seu contexto histórico, não podemos deixar de reparar como tudo neles se organiza em torno de uma história de amor" (TRINDADE, 2010, p. 115).

81. "O conflito entre as duas categorias sociais, ricos e pobres, dilui-se, pois, num conflito sentimental que desaparece assim que as classes superiores integram no seu seio as personagens das classes inferiores" (GRANJA, 2001, p. 201).

82. AREAL, 2014.

83. Segundo Leonor Areal, para além das cenas que ameaçam a estabilidade do casamento, os principais tabus visados pela censura são: a "guerra", a "miséria", as "oposições de classe", o "beliscar a religião" e "mencionar o poder" (AREAL, 2013, p. 340).

84. AREAL, 2013, p. 340. 
85. FREIRE, 2013, p. 58.

86. FREIRE, 2013, p. 58.

87. Cf. VAQUINHAS, 2011, p. 13.

88. Temos aqui de concordar com Anália Torres, quando refere que "a conjugalidade inscreve-se em relações e trajectórias sociais e de género", isto é, "ela ocorre num dado momento do percurso pessoal de um significativo conjunto de indivíduos, percurso esse social, cultural e ideologicamente marcado de forma diferenciada, de acordo com as condições de existência e com o género, já que é diferente também o que se considera ser o comportamento adequado para os dois sexos em sectores sociais distintos" (TORRES, 2000, p. 137).

89. Modelo tradicional e conservador que, a partir da proposta de tipificação de Anália Torres (cf. TORRES 2000", pp. 216-219), Susana Costa Santos sintetiza da seguinte forma: “A forma de conjugalidade institucional tem como base a instituição matrimonial; o casamento e a família são altamente valorizados, sendo através destes que o indivíduo adquire o seu estatuto de adulto. 0 casamento é imposto como destino composto por um conjunto de regras que implicam o cumprimento de papéis diferenciados, responsabilidades e deveres. Homens e mulheres têm papéis distintos - instrumental e expressivo, mesmo quando as mulheres também desempenham um papel instrumental e trabalham fora de casa. 0 romance e o erotismo localizam-se fora do casamento e são para ser vividos no masculino e não no feminino" (SANTOS, 2002, p. 136).

90. Segundo uma publicação do regime destinada às mulheres, "não é grave que uma mulher não saiba traçar o projecto de uma ponte, gerir uma empresa, defender uma causa nos tribunais escreveu alguém; mas é gravíssimo que não esteja em condições de cuidar de uma criança ou de governar uma casa" (Mocidade Portuguesa Feminina - 25 anos de actividade/1938-1963, Lisboa, s. d., p. 39, cit. Por GRANJA, 2001, p. 225).

91. TRINDADE, 2010, p. 124.

92. Cf. CASCÃO, 2011, p. 22.

93. Cf. CASCÃO, 2011, p. 22.

94. Por isso Sofia Aboim, abordando um período sequente (de 1950 aos nossos dias) já pautado por mudanças muito significativas em termos de vida conjugal dos portugueses, afirma que "[...] a vida conjugal alterou-se radicalmente. Modificou-se a forma de escolher um parceiro e de com ele viver e ter filhos, de organizar o trabalho e o sustento, de fazer projectos e tecer esperanças de bem-estar amoroso. As histórias românticas do 'foram felizes para sempre', que a Igreja Católica transformava em dever-ser institucional, começaram a ser olhadas com maior desconfiança à medida que o divórcio se banalizava e nas vidas a dois eram tantas vezes postas a descoberto infelicidades e violências" (ABOIM, 2011, p. 81).

95. Atendendo que "as ideias, as orientações normativas e os valores sobre os domínios da conjugalidade, da família e da sexualidade vão mudando, como é particularmente visível nos últimos 40 anos" (TORRES, 2000, p. 140).

96. A forma de conjugalidade fusional assume-se como um projecto conjugal e familiar que tem por base a partilha de afectos; "o projecto caracteriza-se assim como 'fusionalmente' parental e conjugal, passando a constituir a aposta central que dá sentido à vida dos indivíduos" (TORRES, $2000^{\mathrm{a}}$, p. 219).

97. TORRES, 2000ª , pp. 216-219; ABOIM, 2011, pp. 80-111.

98. “As concepções da sociologia clássica, de Durkheim a Parsons, em relação à mulher na família (papéis, posições, lugares) eram contrárias à ideia de mulher como indivíduo. As alterações ocorridas nos últimos anos vêm pôr em causa a incompatibilidade entre a mulher como mãe e a mulher como indivíduo autónomo capaz de sustentar economicamente e partilhar com o parceiro o papel de provedor da família. Desse conjunto de transformações é de salientar a entrada massiva de mulheres no mercado de trabalho, bem como a crescente escolarização feminina, sendo de assinalar que actualmente o número de mulheres no ensino superior bem como a taxa de conclusão dos respectivos graus académicos é superior à masculina, (ver J. 
Ferreira de Almeida, A. Firmino da Costa e Fernando Luís Machado 1994, 'Recomposição socioprofissional e novo protagonismos' em Portugal 20 anos de democracia), uma maior aceitação do divórcio, a descida da taxa de natalidade associada às modificações no acesso à sexualidade e à procriação, a tendência, mais ideal que real, para a divisão de tarefas entre homens e mulheres nas relações conjugais" (SANTOS, 2002, p. 133).

\section{RESUMOS}

O objetivo deste artigo é compreender o fenómeno da propaganda indirecta no cinema enquanto dispositivo ideológico de controlo da vida privada, identificando a forma como foram tratados os papéis do feminino e do masculino no que à intriga amorosa conducente ao casamento diz respeito.

Para o efeito, foram analisados, à luz do contexto sociocultural e político das duas primeiras décadas do Estado Novo em Portugal, sete filmes de 'comédia à portuguesa' marcantes do chamado 'período de ouro' do cinema português.

A análise comparada do enredo faz emergir um paradoxo: por um lado, o casamento, tido à luz da época como epicentro da vida privada e unidade primária da vida social e afetiva, é naturalmente um dos tópicos centrais nessas narrativas - tudo se encaminha para ele como concretização e realização individual. Porém - salvo raríssimas exceções -, nada dele é retratado. A sua vivência exterior ou social, e sobretudo quotidiana, privada, é omissa. Tratado dessa forma, o casamento não é mais do que um "desfecho ornamental" e uma utopia: o círculo da vida comum a dois nunca é invadido pelo espetador.

This article focuses on seven well-known feature films of the so-called "golden period" of Portuguese cinema - A Canção de Lisboa (1933), O Pai Tirano (1941), o Pátio das Cantigas (1942), o Costa do Castelo (1943), A Menina da Rádio (1944), A Vizinha do Lado (1945), and O Leão da Estrela (1947) - in order to address the way female and male roles were presented while in the process of courtship leading to marriage, during the first two decades of Estado Novo (New 20. State) (1930-1950) - a very conservative dictatorial regime with close relations to the Catholic Church. For that, we will look into some correlated topics: the way rituals of display of affection were dramatized on the big screen, the "seduction" strategies, the dating protocols, the role of modesty and of family surveillance, the way marriage was idealized and how it was envisaged as a life project, the dealing with passional dilemmas, the forbidden loves, the extramarital relationships and the love triangles.

\section{ÍNDICE}

Keywords: cinema, marriage, propaganda, Portuguese comedy in old-fashioned style, Estado Novo

Palavras-chave: cinema, casamento, propaganda, comédia à portuguesa, Estado Novo 


\section{AUTOR}

\section{BRUNO MARQUES}

IHA, FCSH, Universidade Nova de Lisboa, Portugal.

brunosousamarques@gmail.com

Investigador Bolseiro FCT em Pós-doutoramento no Instituto de História da Arte da Universidade Nova de Lisboa, onde coordena o cluster Photography and Film Studies. Professor Auxiliar Convidado no Departamento de História da Arte da Universidade Nova de Lisboa desde Fevereiro de 2016. Coordena a linha de investigação "Retóricas do Corpo" no âmbito do Projecto FCT "Fotografia Impressa. Imagem e Propaganda em Portugal (1934--1974)" [PTDC/CPC-

HAT/4533/2014]. O seu trabalho de investigação centra-se em: Estudos de género e políticas de sexualidade na fotografia, cinema/videoarte e performance arte; Voyeurismo e vigilância; Vida privada e intimidade; Pornografia e erotismo; Liberdade de expressão e censura; Retóricas do corpo e propaganda no Estado Novo; Identidade e retratística.

Bruno Marques is a Post-doctoral Fellow at the Institute of Art History, Faculty of Social Sciences and Humanities, Universidade NOVA de Lisboa, Portugal, where he currently coordinates the research group "Photography and Film Studies". Lecturer at FCSH/NOVA (Dept. of History of Art). Team member of the PhD program in Art Studies/FCSH/NOVA. Member of the Project "Printed Photography: Image and Propaganda in Portugal (1934-1974)" [PTDC/ CPCHAT/4533/2014], financed by FCT. Research Interests: Contemporary Art; Gender Studies and Sexual Politics in Photography, Film, and Performance; Body and Propaganda in New State in Portugal; Voyeurism and Surveillance; Privacy and Intimacy; Pornography and Eroticism; Freedom of Speech and Censorship; Identity and Portraiture. 